\title{
Cultural antecedents of sustainability and regional economic development - a study of SME 'Mittelstand' firms in Baden- Württemberg (Germany)
}

Article

Accepted Version

Kraus, P., Stokes, P., Cooper, C., Liu, Y., Moore, N., Britzelmaier, B. and Tarba, S. (2020) Cultural antecedents of sustainability and regional economic development - a study of SME 'Mittelstand' firms in Baden-Württemberg (Germany). Entrepreneurship \& Regional Development, 32 (7-8). pp. 629653. ISSN 0898-5626 doi: https://doi.org/10.1080/08985626.2020.1713223 Available at https://centaur.reading.ac.uk/89538/

It is advisable to refer to the publisher's version if you intend to cite from the work. See Guidance on citing.

Published version at: http://dx.doi.org/10.1080/08985626.2020.1713223

To link to this article DOI: http://dx.doi.org/10.1080/08985626.2020.1713223

Publisher: Taylor \& Francis

All outputs in CentAUR are protected by Intellectual Property Rights law, including copyright law. Copyright and IPR is retained by the creators or other copyright holders. Terms and conditions for use of this material are defined in the End User Agreement. 


\section{www.reading.ac.uk/centaur}

\section{CentAUR}

Central Archive at the University of Reading

Reading's research outputs online 


\section{Cultural Antecedents of Sustainability and Regional Economic Development - A Study of SME 'Mittelstand' Firms in Baden- Württemberg (Germany)}

This paper examines behavioural and regional/geographic cultural antecedents of sustainability in SME contexts. The study identifies prevailing macrorepresentations of sustainability in the literature and highlights an over-focus on large firms constituting the predominant unit of analysis. Moreover, there is a propensity in the literature to view sustainability primarily in terms of 'environmental' - closely linked to a corporate strategic imperative narrative of economic competitiveness and profitability. Overall, this perspective tends to generate accounts which are acultural, apolitical and ahistorical in terms of innovative actions and sustainability practices. In response, using a conceptual framework of moral identity, the paper develops a more micro-foundational insight to sustainability (developing notions of 'tangible' and 'intangible') and examines regional economic development attitudes at individual owner-manager/managing director level in small-to-medium sized firms.

Methodologically, an inductively-framed interview schedule was employed with owner-managers and managing directors $(n=30)$ of manufacturing SMEs in the Baden-Württemberg region (Germany). The study identified a range of microfoundational behavioural antecedents operating in the sample companies. In particular, it underlined that many of the SME owner-managers/managing directors expressed views informed by a particular moral identity connected with a perspective rooted in regionally bound, longstanding and 'expected' behaviours of trust, fairness, honesty and community responsibility. They viewed themselves as distinctive from larger companies which they saw as pursuing a different orientation based on weaker value systems, short-term performance and market/shareholder returns. In contrast, the sample exhibited longer-term sustainability perspectives based on a deep historical linkage with local culture, community and a sense of obligation towards economic protection of employees.

Keywords: Tangible and Intangible Sustainability, Moral Identity, Behaviour, SME, Germany 


\section{Introduction}

The concept of sustainability has generated a substantial literature encompassing a wide span of domains (Carroll, 1979; Crane and Matten 2010; Brammer and Walker, 2012; Hatak, Floh, and Zauner, 2015; Crilly, Hansen, Zollo, 2016; Cooper, Stokes, Liu and Tarba, 2017). Sustainability literature has, in particular, focused considerable attention on the activities of larger multinational corporate (MNC) entities and their institutional and pan-national macro-contexts typically concerning initiatives on climate change and environmental impacts (Norton et al, 2015). Clearly, this is not to overlook the fact that sustainability may also be linked to issues of, for instance, durability or continuity, nevertheless, increasing and particular attention is required in relation to (environmental) sustainability in other organizational arenas especially small-to-medium sized enterprises (SMEs) (Spence, 2016; Wickert, Scherer, and Spence, 2016). However, in spite of these developments, the predominant macro-orientation in the commentary means that overall the sustainable 'agenda' has tended to be argued and conceptualized in a primarily positivistic conceptual manner (underpinned by historically-rooted scientific concepts of linearity, metrics, causality and representationalism). This predilection causes attention to be focused on a number of recurrent dimensions. First, 'the firm' (and particularly MNC firms, involving relatively apolitical, acultural, ahistorical representations of the people within it) constitutes the principal unit of analysis and sense-making in many sustainability studies (Stokes, 2011; Clegg, 2012). Second, there is a tendency to view sustainability through largely an environmental or 'green'(-wash) orientated gaze (Urry and Larsen, 2011) which focuses on physical dimensions such as: recycling, energy, climate change initiatives and responses, and resource conservation. These are, of course, laudable but there are also important cultural, regional, social and micro-political 
perspectives which also need to be integrated with this environmental-oriented perspective. Third, the preoccupation with tangible and physical aspects is often aligned with framing sustainability primarily in terms of (positivistic) gains of efficiency, effectiveness, competitiveness, performance and profitability, rather than more local and individual-level cultural and sociological imperatives. We argue that this remains an important gap in the literature stream on sustainability management studies.

Consequently, there have been fewer studies within the sustainability field which examine the enacting power of micro-behavioural aspects, the roles and influence of individual actors, and the local contexts in which they are situated (Markman et al. 2016). The present study addresses the identified theoretical gap by exploring antecedents of SME owner-manager/managing director engagement with sustainability linked to the idea of local, cultural, and historical contexts. More specifically, by focusing on individual and micro-dimensions, it particularly considers the dynamics surrounding individual owner-manager sensemaking (Weick, 1995) and its implications for understanding the realities of sustainability (Shevchenko, Lévesque and Pagell 2016). Moreover, the paper draws on the role of moral identity in the formation of attitudes towards sustainability in specific spatial-cultural contexts (following Anderson and Smith, 2007; Korsgaard and Anderson, 2011). Empirically, the study undertakes an inductive investigation of the manufacturing-orientated region of Baden-Württemberg in South-Western Germany. Given its strong sense of regional identity, this area is a pertinent site in which to examine the amalgam of socio-cultural and economic antecedents and micro-foundational factors operating as drivers for sustainability actions in SMEs settings. The paper addresses the following research question:

- What are the antecedents and factors which drive SME owner-manager behaviour in relation to sustainability and regional/local economic dynamics? 
The paper proceeds as follows: first, it undertakes a review of the literature on sustainability related to SME contexts. It then introduces and elaborates the notion of moral identity and examines this in connection with socio-cultural antecedents. Subsequently, the research design is explained and empirical findings of the study are presented. The final section concludes the study by discussing implications, limitations, and future research directions and the paper provides a number of contributions to the sustainability literature from a micro-foundational perspective.

\section{Literature Review}

\section{SMEs and Sustainability}

Sustainability is a relatively young and evolving field which has nevertheless received considerable scholarly attention (Imram, Alam and Beaumont, 2014; Bansal and Hoffman, 2010; Elkington, 1997; Starik and Marcus, 2000). Like its kindred domains, such as CSR, sustainability and responsibility, are: 'essentially contested concepts' (Bakker, Groenewegen and Hond, 2005; Okoye 2009). In the case of sustainability, despite repeated attempts to define the term there does not exist a generally accepted definition in the literature (Lozano, 2008; Mathieu, 2002; Parkin, Sommer and Uren, 2003; Rogers, Jalal and Boyd, 2008; Montiel and Delgado-Ceballos, 2014). This may be the result of the fact that sustainability has necessarily iteratively developed in tandem with increasing pressures on institutions and companies in order to take account of environmental and corporate social responsibilities (Basu and Palazzo, 2008; Friedman, 1970; Solomon and Martin, 2004). Indeed, Hopwood, Mellor and O'Brien (2005: 35) argue, alluding to linkages between the local and the macro-contexts, that: 'the concept of sustainable development is the result of a growing awareness of the global links between mounting environmental problems, socio-economic issues to do with poverty 
and inequality, and concerns about a healthy future for humanity.' Nevertheless, it is important to note that, overall, sustainability commentaries have tended to focus, predominantly on issues concerning environmental, or what may be termed 'green' issues, recycling, energy and resource conservation of sustainability as opposed to, for instance, social, cultural, behavioural or even funding dimensions (Calic and Mosakowski, 2016).

In order to characterize these foci, the present argument, introduces and employs the notion of 'tangible' sustainability for such environmental/performativity focused views. This is due to the fact that these representations are largely characterised by their focus on physical resource conservation in association with overall national, pan-national and global economic macro-concerns of efficiency, effectiveness, growth, performativity and profitability. Such 'tangible' representations tend to constitute the predominant casting of sustainability.

There is thus an important gap in the extant literature. In contrast to 'tangible' sustainability, 'intangible' sustainability points at constructions of sustainability which are intrinsically connected to aspects such as behaviour, values, culture and identity often played out through local and micro-focused idiosyncrasies and individuals operating in socially constructed situations. Intangible sustainability suggests spaces in which individuals connect with, or socially enact, sustainability but not necessarily or automatically for 'tangible'-type sustainability rationale or objectives (resonating with De Clercq and Voronov's (2011) notion of competing logics). Thus, intangible sustainability represents a more oblique engagement with sustainability but can be very important in ensuring the durability and continuity of organizations and networks. Moreover, it is important to differentiate 'intangible' sustainability from existing debates which occur in connection with sustainability in relation to kindred but different domains 
- for instance, intangible assets, which encompass brand value (Liu et al, 2018), intellectual property, and corporate reputation and contrast with tangible assets such as buildings, stock or equipment. The introduction of a concept of 'intangible' sustainability surfaces a novel arena of values and behaviours which is difficult to observe but significant offering an opportunity to recast dominant corporate imperatives. The notion of intangible sustainability connects well with a number of emergent themes in responsible and sustainability debates whereby sustainability can be understood as a phenomenon which: '.. encompasses economic, environmental and social issues that have business implications' (Asif et al., 2011, p. 354). Moreover, Dyllick and Hockerts (2002) signal the potential significance of linkages of the social and the responsible with the longer-term. Importantly, this introduces a temporal dimension which can be employed to look beyond many organizations' propensity to emphasize metrics such as short-term profits, share prices and growth targets which potentially conflict with a longer-term mind-set and issues.

Furthermore, the distinction between tangible and intangible sustainability can be underscored by more profound paradigmatic divisions and underpinnings. A focus on linking sustainability to short-term gains in efficiency, effectiveness and performativity metrics points at the articulation of particular positivistic and managerialistic assumptions which have operated as the dominant paradigms shaping management conceptualisation during much of the twentieth century and subsequently (Lyotard, 1984; Boje, Gephart and Thatchenkery; Stokes, 2016). In other words, the conceptual subtext of large areas of work on (tangible) sustainability portray (if not openly acknowledge) sustainability as something to be employed principally to make the firm grow and survive, so as to continue achieving ongoing and higher returns rather than, for instance, embracing cultural, social or moral motives (Korsgaard and Anderson, 2011). Moreover, as noted 
above, linked with positivistic agendas, much analysis of sustainability has tended to focus on the macro- 'firm' or 'organizational' unit (in conjunction with 'tangible' green and environmental concerns) and how these inform and improve firm performance and profitability or commensurately, image and reputation. Furthermore, in association with the above-noted propensities, the literature on sustainability has had a predilection towards the study of large-scale enterprises, institutional frameworks and multinational corporation firms (MNCs) rather than SMEs and associated micro-dimensions (Lee, 2008; Lindgreen and Swaen, 2010).

The focus on larger enterprises in relation to sustainability is curious since, paradoxically, SMEs constitute a significant proportion of contemporary Western economies (EU, 2006) and this means that, in addition to economic impacts, they are also likely to have substantive impacts on socio-cultural (i.e. behavioural) factors as well as the tangible environmental sustainability issues. Consequently, while there is no doubt that SMEs play a significant role in terms of employment levels, research also indicates that SMEs account for approximately 70 per cent of overall environmental pollution (Hilary, 2000) - a prescient point in relation to sustainability initiatives. Furthermore, differences in size between SMEs and multi-national corporations (MNCs) are prone to producing differences in respective economic, organizational and behavioural characteristics. Welsh and White (1981) appositely underline that small enterprises tend to have an extreme range of forms and that the nature of small business is not similar to a little big business. In particular, research agendas have turned to understanding SMEs, and especially their behavioural dimensions, and role within society (Jenkins, 2004; Morsing and Perrini, 2009; Spence, 1999, 2007; Thompson and Smith, 1991).

In addition, contemporary conceptual work has also pointed at the implicit, embedded and hence often occluded nature of SME sustainability practices which are in 
stark contrast to the very public presentations and impression management activities undertaken by MNCs (Wickert et al., 2016). However, besides (positivistic) economic and organizational rationales, behavioural rationale can also significantly affect SME behaviour and practices, exemplified, by way of illustration, in SMEs' talent management practices (Stokes et al., 2015). Thus, the sustainability literature encourages study of the SME context more closely, and in particular, the individual behavioural microfoundations of sustainability practices in SMEs (Markman et al. 2016). This paper aims to fill this important gap by examining the micro-foundational cultural, behavioural and moral identity antecedents linked to 'intangible' and 'tangible' perspectives of sustainability in an SME context.

Having elaborated the foci, purposes and intended contribution of the paper in relation to micro-foundational dimensions, SMEs and sustainability, the next section of the paper considers the role of moral identity in relation to these issues.

\section{Micro-foundations of Sustainability: SMEs - Intangible Sustainability and the Role of Moral Identity}

The concept of moral identity examines deep values, beliefs and attitudes which drive human behaviour and seeks to understand what propels people to act for the benefit and well-being of others (Piaget 1932; Kohlberg, 1971; Rest, 1979; Aquino et al., 2009). Moral identity is seen as being potentially derived from both cognitive development and socio-cognitive development sources (Aquino et al, 2009) and points at a wide range of interlinked terms including: moral awareness, moral reasoning, moral judgment, moral sensitivity, moral character, moral behaviour and moral action (Villegas de Posada and Vargas-Trujillo (2015). 
Overall, research reveals the important role of moral identity in affecting prosocial behaviour (i.e. behaviour which affirmatively reinforces conduct in varying situations) in organizations. For instance, leader moral identity is indicated as being positively related to ethical leadership (Mayer et al., 2012). Furthermore, there has been allusion to the fact that moral identity may moderate employees' reactions towards sustainability-type issues by addressing the micro-level perspectives (Rupp et al, 2013). Moral identity can also significantly be affected by contextual and localised factors (Anderson and Smith, 2007). For instance, when a situational factor decreases the current accessibility of moral identity, it weakens the motivation to act morally (Aquino et al., 2009; De Groot and Steg, 2009; Shao, Aquino, and Freeman, 2008).

Thus, while a significant amount of work has been undertaken on moral identity, less has been developed which connects the concept to sustainability in a microfoundational temporal and specific geographical spatial manner in SME contexts. In the specific case of the SME setting, Spence (2016) has signalled SMEs' primary challenge as survival and their permanence as going concerns. This generates tensions with moral choices and moral identity in relation to issues such as sustainability. For many MNCs, the nature of the 'short-term' dictates the conditions of cyclical reporting and results to shareholders. For resource-constrained SMEs the 'short-term' can often risk jeopardizing the firm and, naturally, has to be addressed in an ongoing manner to ensure the longevity of the company. Therefore, in the SME context, sustainability needs to be contextualised through a short-term/long-term temporal dialectic of endurance rather than necessarily through a 'green' environmental 'symbolic'-type perspective. In contrast to MNCs, which may use sustainability as a strategic tool and communicate explicitly to obtain symbolic competitive advantages, SMEs are more likely to view and inform sustainability in alternative manners, i.e. linked to community, employees etc (Shepherd and Patzelt, 
2011). Consequently, the latter provide an important empirical setting for the conceptual and theoretical advancement of research on implicit and embedded i.e. intangible forms of sustainability in local contextual settings. Moreover, in the micro-settings of SME contexts, owner-managers, as key agents are enacting and reproducing moral identity and they are likely to play a disproportionately significant role in setting policy, atmosphere and direction in most aspects of the firm (Mayer et al., 2012).

While moral behaviour is founded in the individual, he or she is nevertheless situated in relation to a community or larger entity and companies (especially SMEs) tend to be viewed as being importantly and closely connected to their local community (Habisch, 2004). The findings of Pret and Carter (2017) indicate that embeddedness in a community increases the willingness of entrepreneurs to collaborate. Moreover, the importance of localized elements also reinforces the influence of cultural contextual factors wherein moral identity and moral emotion manifest varying effects in crosscultural situations (Chang, Weaver, and Kim, 2015; Xing, Liu, and Cooper, 2018). Extant research offers insights on the socially enactment of entrepreneurial behaviour in SMEs in varying country contexts (Avram and Kühne, 2008; Uhlaner et al, 2012; McKeever, Anderson and Jack 2014). However, there is strong indication that the role of key individuals (i.e. SME owner-managers) in the wider social and cultural (indeed national/regional) dimensions merit enhanced attention as they play an important role in the formation and role of moral identity in relation to sustainability at a microfoundational level. The argument now moves to examine a context specific exploration of sustainability in an SME localised context by developing a case for the consideration of moral identity and owner-director behaviour in relation to sustainability in a specific German context. Table 1 below summarises the arguments of tangible and intangible sustainability from a comparative perspective: 
Characteristics

\begin{tabular}{|l|l|l|}
\cline { 2 - 3 } \multicolumn{1}{c|}{} & \multicolumn{1}{c|}{ Tangible Sustainability } & \multicolumn{1}{c|}{ Intangible Sustainability } \\
\hline Sustainability focus & $\begin{array}{l}\text { Environmental/green-type } \\
\text { issues }\end{array}$ & Values, beliefs, moral identity \\
\hline Unit of analysis & Large firms - MNC & SME/Alternative forms of firm \\
\hline Metrics & $\begin{array}{l}\text { ROI, profit/turnover/quarterly } \\
\text { return }\end{array}$ & $\begin{array}{l}\text { Well-being, security, } \\
\text { consistency, resilience }\end{array}$ \\
\hline Temporal focus & Short-term returns & Longer-term sustainability \\
\hline Underpinning paradigm & Modernism/positivism & $\begin{array}{l}\text { Critical orientated values, moral } \\
\text { identity }\end{array}$ \\
\hline Spatial focus & Global/little connection to local & $\begin{array}{l}\text { Deeply linked to } \\
\text { local/employees and community }\end{array}$ \\
\hline
\end{tabular}

Table 1. A comparison of tangible and intangible sustainability

\section{SME Owner-Directors/Managing Directors and Sustainability: The Role of}

\section{Moral Identity in the Context of Baden-Württemberg, Germany}

The literature provides some useful accounts that describe the fundamental characteristics of SMEs (Burns, 2011; Curran and Blackburn, 2001; Krämer, 2003). However, Germany's regionalism (Wehling, 2004) provides an interesting and revealing case through which to examine micro-foundational issues of moral identity in relation to SME owner-managers and sustainability. In Germany, the notion of 'Mittelstand' is used to describe SMEs but also points at specific localised cultures surrounding them. In the focal case of the German south-western region of Baden-Württemberg (Cost, 2006) Mittelstand manufacturing is a key industry (Lee, Herold and $\mathrm{Yu}, 2016)$. Moon (2007) indicates that the understanding of ideas such as sustainability and responsibility in a business organization is dependent on such national social, economic, governance and environmental systems operating where the firm resides with cultural context determining what is important (Stieb, 2009). Moreover, in the specific German context, the state and 
banks play a major role in shaping political, economic systems, market interactions, environmental issues and corporate governance systems (Habisch et al., 2011; IW, 2005; Winkler and Remišová, 2007; Audretsch and Elston, 2002; Deutsche Bundesbank, 2012), as a co-ordinated market economy (Liu and Meyer, 2018; Xing, Liu, Tarba and Cooper, 2017). Furthermore, Habisch and Wegner (2005) illustrate that Germany's connection with sustainability, responsible management and social movements and entrepreneurship is also deeply-rooted (back to the 1880s) (Heblich and Gold, 2008; Hiss, 2009). Moreover, Kantian philosophy and social duty (Kant 1724-1804) remain influential in Germany and generally contrast with utilitarian free-market Anglo-Saxon/self-interest models (Palazzo, 2002). Hiss (2009) indicates that this form of 'organised capitalism' tends to generate implicit consensus and a long-term social market economy (Soziale Marktwirtschaft) - 'Rhenish capitalism’ (Albert and Rauf, 1996).

At the micro-level, Reindl (2003) also notes that independent and individualistic mind-sets in the region are common and there is tendency to concentrate on 'internal' or local resources rather than looking beyond the boundaries of the firm. He characterises this posture a typical 'do-it-yourself’ mentality (klassischer Selbermacher). Moreover, the population is often associated with thriftiness, diligence and endurance with a propensity for meticulous work and a capacity of inventiveness. The region has a paucity of natural resources, has land-bound access in terms of trade routes and as a consequence, creativity, technical competencies and entrepreneurial thinking have had to evolve (Landeszentrale für politische Bildung, 2001; Cost, 2006). As an ensemble, these regional factors provide important background micro-foundations context which inform the moral identity aspects of SME owner-director behaviour towards sustainability.

\section{Research Methodology}

The authors conducted an in-depth study which focuses on SME owner- 
manager/managing director behaviours towards sustainability in the SME manufacturing sector in a specific European regional and national context. This served to address a paucity of theoretical and conceptual qualitative work on the important Mittelstand /German setting (responding to Walther et al. 2010). Thus, the research design of the paper adopts a qualitative approach following characteristics outlined by Snape and Spencer (2003) providing in-depth and interpreted understanding of this social world of research participants (Fuller and Tian, 2006).

As the study focuses on owner-managers of SMEs, the process of negotiating access to potential firms underlined the severe time restrictions of potential high-level participants. Connected with the interpretive nature of this research, the research design employed a personal semi-structured interview approach in order to allow openness (Alvesson and Ashcraft, 2012; Holstein and Gubrium, 1995; Silverman, 2011).

Given the inductive orientation of this work, combined with the heterogeneity of the SME sector there is no claim to broad representativeness or generalisability in a statistical sense (Curran and Blackburn, 2001). Nevertheless, this does not mean that conclusions of this research are not applicable in a measured manner to other settings, for instance through means of an analytical generalisation (Kvale and Brinkmann, 2009).

The study focuses upon manufacturing firms in Baden-Württemberg for a number of reasons. First, manufacturing firms have the potential to offer a unique insight because they tend to be acutely aware of the potential environmental and energy impacts of their operations and consequently have an ongoing interest in sustainability (Bradford and Fraser, 2008; Holland and Gibbon, 1997; Jenkins, 2006). Second, manufacturing firms have a historical and contemporary cultural importance in the Baden-Württemberg economy (Statistisches Landesamt Baden-Württemberg, 2013). Finally, the research team has familiarity with the region and organizational access to the manufacturing firms 
located in it. The decision to focus on senior level executives/managing directors (following Kincaid and Bright, 1957) was linked to the wide company knowledge they possess and their propensity to infuse their beliefs and attitudes into the firm culture (Healey and Rawlinson, 1993; Carr, 2003; Burton and Goldsby, 2009).

The recruitment of the sample was undertaken via the Chamber of Industry and Commerce in Baden-Württemberg company publically available region, size, sector lists. A list of approximately 180 firms was compiled and all of the companies were contacted to solicit interviews. Identification of the appropriate participants was time-consuming, especially where identification of MD-type roles was not immediately evident (echoing Healey and Rawlinson, 1993). Gatekeepers were primarily assistants to managers, but also frequently receptionists. Initial approach was made by letter followed up via phone call to schedule appointments. From 80 company contacts 30 high-level in-depth interviews were secured. Convenience and snowball sampling were employed to a minimum extent. Interviews were conducted in German and subsequently transcribed and translated. Confidentiality, identifying characteristics of firms and participants and anonymity was ensured. The fieldwork took place between January and August 2014. Overall, 16.67 per cent of the respondents were female. The low percentage of female participants reflects a generally reported low percentage of women in leading positions in German organisations (BMFSFJ, 2010). Therefore, the proportion of female managers in the sample is typical for the German SME sector. All participants were of German nationality and ethnicity and were born in Baden-Württemberg with a wide spread of age 29 years old to 76 years old (mean average was 55 years old). The majority of respondents were experienced business people.

The research was mindful of Gioian insights regarding: assumptions, qualification of the research question, $1^{\text {st }}$ order (literal) and second order (conceptual) analyses linked 
to the general quasi-Grounded Theory of inductive research (Gioia, Corley \& Hamilton, 2013). The analysis approach was based on thematic coding and template analysis (Braun and Clarke, 2006; King, 1998, 2004, 2012) This approach structures analysis in accordance to how they relate to each other allowing a hierarchical order or conceptualization and the identification of emergent of first order and second order themes.

The analysis began with repetitive and intensive reading of the data by the research team members. This worked to develop the reliability of the analytical findings. The first round of readings generated a priori codes. These are, in effect, the main constructs which emerge as apparent and salient from the data set. Having established these initial codes, further repeated readings, developed a series of secondary tier codes which represent phenomena and recognised experiences and perceptions operating within, and in relation to, the a priori codes. During these processes, instances can arise where identified issues or pieces of data cannot be readily situated within identified a priori codes. Here, it was necessary to acknowledge the emergence of a new a priori code from the data.

The table below provides an overview of the structure of themes, which resulted out of the multiple interactions with data described above. The thematic coding approach led to some kind of hierarchical order (King and Horrocks, 2010) consisting of themes, sub-themes and codes (Coffey and Atkinson, 1996; Dey, 1993; Gibbs, 2007). The relation of quotes to the hierarchical order of themes and sub-themes is being illustrated in the discussion of findings.

\begin{tabular}{|c|l|}
\hline Construct (Theme/sub-theme) & \multicolumn{1}{|c|}{ Exemplary codes describing the phenomenon } \\
\hline 1. General personal attitudes of participants & \\
\hline $\begin{array}{l}\text { Mentality of the Owner Manager/ } \\
\text { Managing Director }\end{array}$ & $\begin{array}{l}\text { Self-determination, Assertiveness, Self-evaluation, } \\
\text { Swabian cultural identity }\end{array}$ \\
\hline
\end{tabular}




\begin{tabular}{|c|c|}
\hline Views on large enterprises & $\begin{array}{l}\text { Large enterprise thinking, corporate power, effect } \\
\text { of capital market, arrogant behaviour, personal } \\
\text { distance }\end{array}$ \\
\hline \multicolumn{2}{|l|}{ 2. Characteristics of Mittelstand firms } \\
\hline Traditional descriptive characteristics & Hierarchical levels, resource scarcity, flexibility \\
\hline Nature of tasks & $\begin{array}{l}\text { Width of working tasks, ad hoc mentality, strategic } \\
\text { tasks, operational tasks }\end{array}$ \\
\hline Long-term view & $\begin{array}{l}\text { Developing the firm, growth, economic success, } \\
\text { relationship to customers, relationship to suppliers, } \\
\text { succession, ownership issues, employee fluctuation }\end{array}$ \\
\hline \multicolumn{2}{|l|}{ 3. Societal embeddedness and networks } \\
\hline Local environment & $\begin{array}{l}\text { Local authorities, local society, regional } \\
\text { connection, local employees, regional customers, } \\
\text { regional suppliers, honorary posts }\end{array}$ \\
\hline Activities in the social sphere & $\begin{array}{l}\text { Charity projects, cultural sponsoring, sponsoring } \\
\text { clubs, supporting education }\end{array}$ \\
\hline \multicolumn{2}{|l|}{ Network externalities } \\
\hline Involvement in business associations & $\begin{array}{l}\text { Relevance of sustainability topics, SME business } \\
\text { associations, sustainability business associations, } \\
\text { regional associations, traditional business } \\
\text { associations, industry specific associations }\end{array}$ \\
\hline Co-operations & Research facilities, firms \\
\hline \multicolumn{2}{|l|}{ 4. Employees } \\
\hline Importance & $\begin{array}{l}\text { Shortage of qualified labour, representing a success } \\
\text { factor, valuing employees in a more general sense }\end{array}$ \\
\hline Employee-oriented culture & $\begin{array}{l}\text { Close relationship, job security, treating employees } \\
\text { fairly, equality of chances, pressure and workload, } \\
\text { supporting employees in difficult situations }\end{array}$ \\
\hline Activities & $\begin{array}{l}\text { Vocational trainings, continuous training, financial } \\
\text { benefits, flexible working time, health } \\
\text { management, ergonomic working conditions, } \\
\text { providing additional facilities, job rotation, events }\end{array}$ \\
\hline \multicolumn{2}{|l|}{ 5. Ecological dimension } \\
\hline Importance & $\begin{array}{l}\text { Legal regulations, environmental awareness, lower } \\
\text { relevance of environmental issues }\end{array}$ \\
\hline Activities & $\begin{array}{l}\text { Recycling, biodiversity, integrating ecological } \\
\text { considerations in products, preventing pollution, } \\
\text { vehicle fleet, improving processes, using green } \\
\text { electricity, producing green energy, saving energy, } \\
\text { saving resources }\end{array}$ \\
\hline \multicolumn{2}{|l|}{ 6. Business practices and principles } \\
\hline \multicolumn{2}{|l|}{$\begin{array}{l}\text { Mittelstand approach of doing business } \\
\text { with each other }\end{array}$} \\
\hline Moral and ethical issues & $\begin{array}{l}\text { Norms and values, critical working conditions, } \\
\text { arms industry, corruption, subsidies, management } \\
\text { remuneration, purpose of a firm }\end{array}$ \\
\hline Reflection & Evaluating own engagement \\
\hline \multicolumn{2}{|l|}{ A. Integrative theme: management approach } \\
\hline General management approach & Formalisation, employee empowerment \\
\hline
\end{tabular}




\begin{tabular}{|l|l|}
\hline Management approach employees & $\begin{array}{l}\text { Systematics, management guidelines and values, } \\
\text { feedback culture, survey tools, key performance } \\
\text { indicators }\end{array}$ \\
\hline $\begin{array}{l}\text { Management approach ecological } \\
\text { dimension }\end{array}$ & $\begin{array}{l}\text { Works suggestion scheme, form of the management } \\
\text { system, benefits, problems }\end{array}$ \\
\hline Selecting social activities & $\begin{array}{l}\text { Local relationship, resource orientation, win-win } \\
\text { approach, implementation dynamics }\end{array}$ \\
\hline
\end{tabular}

Table 2. Illustrating the hierarchical structure of themes, sub-themes and codes

\section{Findings}

The data surfaced a range of issues and antecedents linked to moral identity which inform and drive attitudes to micro-foundations of sustainability in the particular context surrounding the sample SMEs. The findings are presented within the emergent themes elaborated below.

\section{Owner-Manager Mentality Linked to Cultural Regional Identity}

Within the Mittelstand firms of Baden-Württemberg context the issue of 'selfdetermination' and 'autonomy' (Chaston, 2010) emerged as vitally important. Here, 'selfdetermination' was characterised by the idea of taking responsibility for action on behalf of others:

'I am an entrepreneur. I want to do things, yes, I want to change things.'

(Owner-Manager Company AD)

'In Mittelstand firms, I see the possibility of self-realisation. There is less politics. There is the chance to participate with your skills and influence and create a company.' (Owner-Manager Company D)

This respondents desire for freedom so as to be able to accomplish and transform existing situations was recognized as important. This is in line with the overall entrepreneurial verve (Davidsson, 2004; Storey and Greene, 2010), but tends to be 
anchored more strongly in the local Swabian identity of participants (see also Cost, 2006, Herrigel, 1996; Weber and Wehling, 2012), especially in contrast to SMEs of other countries, for which also a status quo mentality can be observed in literature (Hankinson, Bartlett and Ducheneaut, 1997). It should be underlined that the generally expressed principal objective supporting this motivation was not necessarily maximising profits but appeared to be a wider social mission:

'But personally, I am interested in other things [than just profit and economics]. Personally, it is important to me that I can continue to decide freely.' (Owner-Manager - Company AD)

These comments pointed at a predisposition towards deeper motives held by owner-managers which operated in tandem with a disciplined hardworking mentality (see also Koiranen, 2002) that was particular evident in challenging situations - an environment which is heavily influenced by the broader mind-set of the 'BadenWürttemberg context':

'We do not want to grow and expand [endlessly]. But the main orientation is traditionally Swabian [i.e. regional and cultural]. I tend to say - Do always what you can. Be careful not to overstrain yourself. This also equals the principle of sustainability. These are the basic conditions.' (Owner-Manager - Company O)

Here, the regional cultural background (Cost, 2006; Weber and Wehling, 2012; Wehling, 2004) ('Swabian' - i.e. a cultural identity associated with this historical region in southern Germany which encompasses Baden-Württemberg) is used by the respondent to explain that the goal is not to grow 'at all costs' but simply to do what is possible and not get drawn into the pursuit of maximum growth regardless of how this might be manifested (i.e. sales volume, turnover or profit). So, this participant recognises that there 
are spatial limitations to what can be achieved or, more specifically, to what should be achieved. Importantly, this limitation is internally focused, although influenced by externally imposed values, and is strongly connected to notions of risk aversion. It is interesting that this self-imposed restriction appears linked to wider notions of sustainability. It does not appear to be narrowly linked to uniquely green or environmental issues but rather concerned with a temporal dimension of endurance and longevity of the firm as a social vehicle for the community. The theme of Swabian values of thriftiness and caution are also reflected in the following observation made by a Managing Director:

'We have started energy management in a classic way, simply like Swabians do it. During the crisis in 2008-09 we said: Now we have to save everywhere.' (Managing Director - Company Y).

Modesty and thriftiness are historically part of the culture of the local Swabian people (Bechtle and Lang, 1999; Cost, 2006) and provide important cultural antecedents for the approach towards sustainability in SME settings.

\begin{tabular}{|l|c|}
\hline $\begin{array}{l}\text { Additional quotes referring to the sub-theme mentality of the Owner- } \\
\text { Manager / Managing Director, which could be identified as a powerful } \\
\text { moderator }\end{array}$ & Code \\
\hline $\begin{array}{l}\text { 'Unbelievable. It is, how do we say. I am the architect of my own fortune. That is } \\
\text { the huge difference.' (Company C) }\end{array}$ & $\begin{array}{c}\text { Self- } \\
\text { determination }\end{array}$ \\
\hline $\begin{array}{l}\text { '....and I will have to work till I am 70 years old, however it is not like work, it is } \\
\text { self-realisation. Of course, with ups and downs.' (Company K) }\end{array}$ & $\begin{array}{c}\text { Self- } \\
\text { determination }\end{array}$ \\
\hline $\begin{array}{l}\text { 'Stability. Stability. Satisfaction. I mix entrepreneurship and the life within the } \\
\text { company with my private life.' (Company D) }\end{array}$ & $\begin{array}{c}\text { Self- } \\
\text { determination }\end{array}$ \\
\hline 'There is a greater degree of freedom.' (Company F) & $\begin{array}{c}\text { Self- } \\
\text { determination }\end{array}$ \\
\hline $\begin{array}{l}\text { 'It is often that people say, you are sitting here, you are the boss, you can decide } \\
\text { this now. Then, I reply, yes, the good thing is that I can decide when I decide, and } \\
\text { I do not decide now. This is the difference...nobody can force me to decide.' } \\
\text { (Company O) }\end{array}$ & $\begin{array}{c}\text { Self- } \\
\text { determination }\end{array}$ \\
\hline $\begin{array}{l}\text { 'And this gives you freedom, you do not have to ask, if you have the freedom as } \\
\text { an Mittelstand entrepreneur to do such things [i.e. projects, investments], to also } \\
\text { have the courage.' (Company W) }\end{array}$ & $\begin{array}{c}\text { Self- } \\
\text { determination }\end{array}$ \\
\hline $\begin{array}{l}\text { 'We were brought up like this [in Baden-Württemberg]: saving, yes recycling. } \\
\text { This is rooted in our mindset, yes. Totally.' (Company M) }\end{array}$ & $\begin{array}{c}\text { Swabian cultural } \\
\text { identity }\end{array}$ \\
\hline $\begin{array}{l}\text { 'The relationship to the local region here [in Baden-Württemberg] is stronger.' } \\
\text { (Company P) }\end{array}$ & $\begin{array}{l}\text { Swabian cultural } \\
\text { identity }\end{array}$ \\
\hline
\end{tabular}


Table 3. Additional quotes substantiating the Owner-manager mentality in the context of the Swabian cultural background

The moral role of the firm and its owner-managers in ensuring the sustainability of the community through maintaining skills and conditions for employees was evidenced through a number of illustrative employee-related mechanisms identified in the sample SMEs. Examples included: provision of vocational and continuing professional training; financial incentives such as profit sharing and incentive schemes; health schemes; flexible working arrangements; ergonomic work assessments; job rotation (in order to maintain interest); social events (Christmas fetes etc.) The following table shows further quotes from data substantiating the discussed findings above:

\begin{tabular}{|l|c|}
\hline Additional quotes referring to the sub-theme employee oriented-culture & Code \\
\hline $\begin{array}{l}\text { 'When our teams through innovation, in which I was not involved in an } \\
\text { operational sense but often enough acted as a visionary, projects after 20 years, } \\
\text { lead to attractive products for our customers...' (Company K) }\end{array}$ & $\begin{array}{c}\text { Representing a } \\
\text { success factor }\end{array}$ \\
\hline $\begin{array}{l}\text { 'You always have to remind yourself, without employees, without good } \\
\text { employees nothing works. You cannot do it by yourself. You have to integrate } \\
\text { yourself and you need to be aware of your responsibility.' (Company O) }\end{array}$ & $\begin{array}{c}\text { Representing a } \\
\text { success factor }\end{array}$ \\
\hline $\begin{array}{l}\text { 'The regional connection leads to a closer relationship to the people and it helps } \\
\text { to remain grounded. You talk to everyone. Hauteur and arrogance are not } \\
\text { acceptable.' (Company Q) }\end{array}$ & Close relationship \\
\hline $\begin{array}{l}\text { 'I would say that I know 60 to 70 per cent of employees by name. This certainly } \\
\text { is also a criterion for a Mittelstand company.' (Company Y) }\end{array}$ & Close relationship \\
\hline $\begin{array}{l}\text { '..., because simply the humanity tends to be a bit more in the foreground...' } \\
\text { (Company Z) }\end{array}$ & Close relationship \\
\hline $\begin{array}{l}\text { 'You do have responsibility over the time, in the course of years. And when you } \\
\text { have employees, you have to think about the families.' (Company AB) }\end{array}$ & Close relationship \\
\hline $\begin{array}{l}\text { 'You really grow together, when you have long-standing employees.' (Company } \\
\text { AE) }\end{array}$ & Close relationship \\
\hline
\end{tabular}

Table 4. Additional quotes exemplifying the close relationship to (local) employees

\section{Engagement with Environmental Sustainability: Economics and Community}

In relation to direct engagement with the 'green' environmental aspects of sustainability interestingly there was a mixed set of reactions. On the one hand, there were respondents who expressed a wish to engage with sustainable activities albeit more linked to legal 
compulsion:

'To me this means complying with certain laws. I have to implement certain ecological procedures to be able to work. The regulations are becoming more severe and we have to build a new hall because the older one does not meet the standards any longer, or we must introduce new processes. No, for me it is important to care about sustainability.' (Owner-Manager - Company D)

This participant can be viewed as an environmentally conscious owner-manager role model as he is strongly engaged in a variety of different activities ranging from extremely efficient production processes to making use of regenerative energy and striving to be carbon neutral. He is also willing to implement activities that do not offer a positive financial return and, thus, also accepts higher costs, as he is personally interested in new technologies, especially those related to the environment. Another aspect mentioned by the participant was that, in the past, the firm's profits have been re-invested in the firm and in ecological projects. These data reveal two issues. First, they emphasise the overall importance of the attitudes and beliefs of the owner, as also indicated by Burton and Goldsby (2009) and recently supported by Boiral et al. (2014). The findings here are supported by Hatak et al. (2015), who found that where there is a positive attitude towards sustainable development. This is a seminal motivation for initiating more sustainable business practices. Second, Enderle (2004) signals this as spaces of freedom to engage in sustainability and responsibility issues. Many firms in the sample find themselves in challenging competitive positions achieving only low margins. In such firms, there is limited space for engaging in 'green' tangible sustainability beyond legal obligations. However, the data also indicate that there are firms in the sample which generate good profits. Perhaps the question here is not if there is an overall scope for freedom of action but more if, from the subjective point of view of the owner or ownermanager, there is moral compunction and mental 'space' to engage more substantially in 
sustainability independent of legal compulsion. The operation of this subjective perspective ultimately appears to determine whether a firm is willing to invest in sustainability activities, and illustrating this, one participant indicated that the firm is in a comfortable financial position, but that the main processes are not yet running smoothly, which relates to limited resources for other purposes such as environmental management:

'The environment does not play a role, whereas we have to pay attention to our products. Indirectly, there are activities such as using new technologies, energy-saving things, but it is not a priority. It would be a lie for one to claim this.' (Managing Director - Company A)

Overall, for sample firms, protecting the environment in an overt manner was not indicated as being necessarily a high priority rather protection of the economic security of the community is important. This was the dominant attitude in most of the sample companies. Many firms are still engaged in a number of activities related to the environment, such as reducing energy consumption, recycling and waste reduction. This is mainly done because it reduces costs but there is an underlying notion of sustainability of the firm as security for employees and its role in the community. While Klein and Vorbohle (2010) found considerable neglect of environmental issues, this cannot be definitively confirmed for the sample used in this research. However, as indicated above, it can be argued that environmental activities are not necessarily carried out because of environmental awareness but in order to reduce costs, legal regulations and linked to a sense of intangible sustainability of the community. Other participants reported that they care for environmental aspects because a modern image and good impression management (Giacalone and Rosenfeld, 1989, Giacalone, Rosenfeld and Riordan, 2001) may help to convince potential customers, as stated by the following participant: 
'When we can prove that we are independent from electricity supply, even give electricity back by means of solar panels, a combined heat and power unit, heat recovery and so on, then the situation is different. Well, market presentation is very, very important. Perhaps it is something like combining useful with enjoyable business.' (Managing Director - Company G)

According to this, investing in environmental activities may provide a benefit that goes beyond pure cost savings, as customers could be more willing to do business with firms that are recognised as 'modern' and associated with a positive image. This may also support attraction of employees, as parts of society now show relatively high awareness of environmental issues (BMU/UBA, 2015; Rogall, 2009) and it is reasonable to assume that even potential employees consider such issues, at least to a certain extent. This allies with Masurel (2007) who found that environmental activities may be rooted in the belief of contributing to the well-being of employees in the present setting and this can be seen as a reinforcement of moral identity in the Swabian context. The following table shows a number of further quotes that allow an in-depth view on parts of primary data, illustrating the attitudes towards environmental sustainability

\begin{tabular}{|l|c|}
\hline $\begin{array}{l}\text { Additional quotes referring to the sub-theme - importance of environmental } \\
\text { sustainability issues }\end{array}$ & Code \\
\hline $\begin{array}{l}\text { 'Activities are important, such as groundwater protection, soil protection and so } \\
\text { on. We do not need to discuss this, nowadays this is self-evident...' (Company F) }\end{array}$ & $\begin{array}{c}\text { Environmental } \\
\text { awareness }\end{array}$ \\
\hline $\begin{array}{l}\text { 'No, no, we have an obligation, an absolute one. No waste, no cent and no } \\
\text { gramme [of i.e. raw material] is being wasted.' (Company M) }\end{array}$ & $\begin{array}{c}\text { Environmental } \\
\text { awareness }\end{array}$ \\
\hline $\begin{array}{l}\text { 'I believe that for us the ecological question is not solved to 100 per cent } \\
\text { satisfactory but we always try to do it better.' (Company O) }\end{array}$ & $\begin{array}{c}\text { Environmental } \\
\text { awareness }\end{array}$ \\
\hline $\begin{array}{l}\text { 'The environment plays an important role. There is the consciousness, I would } \\
\text { say in rural areas the consciousness is more natural and stronger, compared to } \\
\text { cities.' (Company Q) }\end{array}$ & Environmental \\
\hline $\begin{array}{l}\text { 'The things we think about make sense from an environmental and economic } \\
\text { point. We try to do them despite the many related laws, which exist. And one } \\
\text { really has to say that there are many, many laws. But we also have a } \\
\text { certification.' (Company W) }\end{array}$ & Environmental \\
\hline $\begin{array}{l}\text { 'Well, we try to do all in the as ecological as possible, to use resources as few as } \\
\text { possible but I use to say this is also a bit hypocritical. I do not want to present } \\
\text { myself as an environmentalist. It is an economic question.' (Company X) }\end{array}$ & Environmental \\
\hline
\end{tabular}


Table 5. Additional quotes illustrating the view of participants on environmental sustainability

\section{Preference for 'Mittelstand' Approach of Doing Business}

An aspect that became evident in the field data, however was not necessarily widely recognised in the literature (see as an exception Mathews and Stokes, 2013), was that many participants seemed to prefer working with other SMEs. Participants argued that working with other SMEs facilitated productive personal working relationships that led to partner-like collaborations and efficient informal policies and procedures. This way of doing business was described by one participant as follows:

'Yes and this also is the advantage, if you work with a 'Mittelstand' firm. You receive much more understanding; see things on the same eye level. However, I would not say that you could allow everything. This is not possible but there is fairness and do you know what, a word counts, a handshake also counts. You probably know the famous expression of the honourable businessman. This is still true at 'Mittelstand' firms, though barely at large corporations.' (Owner-Manager - Company C)

This quote may partly result from a rather romantic and socially constructed worldview of the participant (Crotty, 1998) and may overdraw the differences in the collaboration between SMEs and large corporations; however, the basic idea notion of a moral identity operating at SME firm level (in counterpoint to MNC interactions) was widely apparent in the data. The nature and mind-set of SMEs, and particularly ownermanagers, seemed to produce relationships grounded on fairness and trust, as informal agreements (a handshake) seem to have similar validity than more formal ones like a written contract. In a similar vein, the Owner Manager of Company AB reports on the experiences of doing business with a large Mittelstand firm having about 2,000 employees and indicates a very respectful, polite and professional collaboration, which 
seems totally different from their relationship with some larger and non-regional entities.

The participant reported on particularly trustful relationships:

'This shows that a relationship was built based on trust and we would like to maintain this. Then you do not say, oh there are no prices on the purchase order form and now you take advantage of this. We do not do that. We remain fair and it also was the case that there was a price on the purchase order, for parts we had produced earlier, which was twice as high. Then we said that this is not correct and so on. Do you know we also have to do such things; you do not simply take advantage of this. You remain fair. And also the other way round. If you say, oh, we miscalculated a bit could we adjust this?' (Owner Manager - Company AB)

One may assume that such behaviour results in perceived moral reciprocal obligations that may ensure the long-term existence of the business relationship (Fuller and Tian, 2006; Portes, 1998; Uhlaner, Goor-Balk and Masurel, 2004). Surprisingly, a relatively low awareness of sustainability, ecological issues and environmental activities (beyond legal references) was identified. The following table underlines the above described specific way of doing business, which is a dominant theme in data:

\begin{tabular}{|l|c|}
\hline $\begin{array}{l}\text { Additional quotes referring to the sub-themes Mittelstand approach of doing } \\
\text { business with each other and views on large enterprises }\end{array}$ & Code \\
\hline $\begin{array}{l}\text { 'Then, I received a call [one day before a meeting]. The appointment has been } \\
\text { cancelled, we will do it on Monday. Not the question: Would Monday suit you? } \\
\text { We will do it on Monday. You understand the difference, right?' (Company N) }\end{array}$ & $\begin{array}{c}\text { Arrogant } \\
\text { behaviour }\end{array}$ \\
\hline $\begin{array}{l}\text { 'Difficult, very arrogant, it is very difficult... [the collaboration with large } \\
\text { corporations].' (Company L) }\end{array}$ & $\begin{array}{c}\text { Arrogant } \\
\text { behaviour }\end{array}$ \\
\hline $\begin{array}{l}\text { 'They [large corporations] really press you for the lowest price. Then he cheekily } \\
\text { said, if you cannot afford to reduce the revenue with us by 10 per cent you must } \\
\text { not do business with us. This truly is cheeky.' (Company AB) }\end{array}$ & $\begin{array}{c}\text { Arrogant } \\
\text { behaviour }\end{array}$ \\
\hline $\begin{array}{l}\text { 'We tend to be in a sandwich position, which sometimes is a bit uncomfortable. } \\
\text { This means we have on both sides large players, and we as a small Mittelstand } \\
\text { firm are between the two.' (Company F) }\end{array}$ & Corporate power \\
\hline 'They [the large corporations] try to exploit their market power.' (Company P) & Corporate power \\
\hline $\begin{array}{l}\text { 'We produce components for the electronic industry, small parts, small prices, } \\
\text { large customers, corporations, price pressure, extremely difficult.' (Company Q) }\end{array}$ & Corporate power \\
\hline $\begin{array}{l}\text { 'And this, of course is a question of lobbyists, of the large corporations, I do not } \\
\text { want to go into detail.' (Company AD) }\end{array}$ & Corporate power \\
\hline
\end{tabular}




\begin{tabular}{|l|c|}
\hline $\begin{array}{l}\text { 'The perspective, the long-term perspective is also a topic at large companies. } \\
\text { Obviously, they do not care at all.' (Company W) }\end{array}$ & $\begin{array}{c}\text { Large enterprise } \\
\text { thinking }\end{array}$ \\
\hline $\begin{array}{l}\text { '...it really is very anonymous. We had a meeting at a trade fair. It tends be that } \\
\text { they pray down to us from a different sphere.' (Company R) }\end{array}$ & Personal distance \\
\hline $\begin{array}{l}\text { 'Do you know, they [large corporations] are afraid of human relationships. } \\
\text { Because they say that then not only ratio and figures play a role,...' (Company }\end{array}$ & Personal distance \\
\hline $\begin{array}{l}\text { Q } \ldots \text { and they are structured in a similar way, as we are [other Mittelstand firms].'. } \\
\text { (Company O) }\end{array}$ & $\begin{array}{c}\text { Mittelstand } \\
\text { approach of doing } \\
\text { business with } \\
\text { each other }\end{array}$ \\
\hline $\begin{array}{l}\text { 'As a Mittelstand firm, you care that all is on an eye level, that it is a partnership, } \\
\text { between supplier and customer.' (Company S) }\end{array}$ & $\begin{array}{c}\text { Mittelstand } \\
\text { approach of doing } \\
\text { business with } \\
\text { each other }\end{array}$ \\
\hline $\begin{array}{l}\text { Mittelstand } \\
\text { 'Our experience is that Mittelstand firms have a better understanding of a } \\
\text { partnership than large corporations.' (Company Z) }\end{array}$ & $\begin{array}{c}\text { approach of doing } \\
\text { each other }\end{array}$ \\
\hline
\end{tabular}

Table 6. Additional quotes exemplifying the importance of a Mittelstand way of doing business

In summary, data indicate a severe dichotomy of SMEs and large corporations, which was partly recognised in literature earlier (Penrose, 2009; Welsh and White, 1991) but seems to be reinforced by the local moral identical context of Swabian culture. This certainly represents an important avenue of further research as the collaboration of the vast majority of SMEs with large corporations is a key for the success of the local economy and recent developments of an erosion of organised 'Rhenish Capitalism' (Dustmann, Fitzenberger, Schönberg and Spitz-Oener, 2014; Hassel, 2014; Hiss, 2009; Matten and Moon, 2008) may continuously affect this relationship.

\section{Personal Moral Identity and Ethical Stances}

Interview discussions revealed information on the moral values and business principles to which participants attached importance. Although aspects such as values tend to be 
very individual matters, the data indicated a number of interesting trends. These aspects could be used to develop a conceptualized notion of what may be described as a model of the 'good and honourable' SME (owner) manager. The conceptualisation consists of aspects that more generally describe the values of participants (i.e. 'norms and values') but also a number of areas expressing ethical attitudes of participants (i.e. 'critical working conditions', 'corruption'). As indicated above, issues of fairness and trust seem to play an important role for many participants:

'We must be able to look into the mirror every morning and say we are fine. Do we communicate this? Large corporations communicate such things and present it. No, we do not have time for this... I would call this healthy social behaviour. Yes, we do follow that; you cannot disguise yourself. For me this means you have to remain authentic, be it at home, in other areas or here at the firm. There is no difference for me.' (Owner Manager - Company B)

The participant seems to be content. For him, this also involves being 'authentic', which probably implies application of the same values and principles to the private and professional spheres (following Carr, 2003). However, this finding is in contrast with the findings of Boiral et al. (2014), who indicate a decoupling of the responsibility of many managers and their values in the environmental field. Owner Manager - Company B certainly cannot be characterised as a 'leader' in sustainability issues and tends to have clear business focus; nevertheless, moral values do play a role for him in the professional sphere. Moreover, he and many others frequently used terms such as 'fairness', 'trust', 'reliability', 'honesty', 'equity', 'respect', 'being open', 'not forcing people to do things', 'not doing harm', and 'obeying legal and moral norms'. Jenkins (2006) found moral and ethical arguments as dominant rationalisation for SMEs to engage in CSR (see also Hammann, Habisch and Pechlaner, 2009). 
Interestingly, Tänzler (2014), suggested that there is no great difference in behaviour of family-managed firms and Mittelstand firms managed by external nonfamily members. A similar observation could be made here, as even external managers showed empathy, closeness and loyalty to their firms and seemed to behave similarly to an owner-manager. However, SMEs also expect to be treated in a reciprocal manner and this may explain why there are certain reservations against the business behaviour of large corporations. Perhaps part of the mentality in SMEs can best be summarised as follows (Owner Manager - Company AD): 'Well, we are quick and honest, and we do what we say.' However, acting in a responsible and value-driven way does include a societal perspective as the following quote suggests:

'This is a societal challenge. Society is separated into the rich and the poor, increasingly so in Germany. We have to be careful that people belonging to the rich class do not lose their moral concepts but instead that we try that this collective, and also the entrepreneurs and MDs can only be entrepreneurs and MDs if there are employees who dirty their hands and control the machines. We must keep this together' (Managing Director - Company Y).

This supports the overall importance of ascribed to employees in SMEs and their management, but puts this in a greater context which demands protecting the cohesion of society in general. This can also be explained by SMEs tending to be spatially closer to the society or (local) community and, consequently, being in a more intense relationship. Thus, one may argue that in SMEs there is greater interest that the society in general is working compared to large corporations, which perhaps are more globally oriented.

While the findings thus far point towards economic aspects it was evident that this is not the sole driver for actions (Fraj-Andrés et al., 2012; Santos, 2011; Sen and Cowley, 2013). The Owner-Manager of Company C saw the objectives as follows: 'I work for the family and not for shareholder value, one is working for the family, but you are also 
working for the existence of the employees.' The participant seems to relate shareholder value with short-term profit maximisation for some external investors, while the focus for him is clearly on the family and employees. Thus, this seems to underline the importance of the family of the owner manager.

'The entrepreneur takes on responsibility. He pays taxes as required. $\mathrm{He}$ employs people. He gives them the possibility to live, to spend money in the economy. This is responsibility. Many speak about the society and responsibility but cannot clearly define it. I am not of the opinion that the entrepreneur exists to hold any social-political sermons and offer suggestions for improvement. Others can do this.' (Owner Manager - Company E)

Here, the Owner Manager - Company E emphasises that companies which act in an amoral way do not only risk diminishing the reputation of the firm but also harm the whole economic (and societal) system.

The following table shows some additional quotes, which allow a further in-depth view into the moral and ethical framework of participants:

\begin{tabular}{|l|l|}
\hline Additional quotes referring to the sub-theme moral and ethical issues & Code \\
\hline $\begin{array}{l}\text { 'The question is, what does the management decide to do with the profit. I say it } \\
\text { a bit provocative: Do I prefer to have yacht in Spain or solar panels on our roof. } \\
\text { A privately owned and family managed company certainly has to decide that. I } \\
\text { invest a lot of money in my company and I have a lot of fun by doing so.' } \\
\text { (Company D) }\end{array}$ & Norms and values \\
\hline $\begin{array}{l}\text { 'Then such things like honesty, reliability, if something is said that you can count } \\
\text { on it, that it will be kept or that you get informed, when something changes.' } \\
\text { (Company F) }\end{array}$ & Norms and values \\
\hline $\begin{array}{l}\text { 'It starts with that the child sees that the father is not looking for tax loopholes, } \\
\text { that the father has a sense for justice, and that he accepts existing rules, } \\
\text { irrespective whether he agrees or disagrees with these rules.' (Company K) }\end{array}$ & Norms and values \\
\hline $\begin{array}{l}\text { 'The worst thing I have ever seen, the worst, this kind of thinking in castes [in } \\
\text { India].' (Company M) }\end{array}$ & Norms and values \\
\hline $\begin{array}{l}\text { 'I prefer that everything runs correctly. I expect that I got treated correctly but } \\
\text { this goes in mutual directions.' (Company N) }\end{array}$ & Norms and values \\
\hline $\begin{array}{l}\text { 'Well, I see it like that, if there is a bit more brightness, a bit more joy, a bit more } \\
\text { harmony in the world due to my existence, that would be good.' (Company AD) }\end{array}$ & Purpose of a firm \\
\hline
\end{tabular}

Table 7. Additional quotes referring to moral values of participants 


\section{Sustainability and Activities in the Social Sphere}

A final dimension that will be discussed here involves the procedures reported by participants when they choose activities to engage the society or local community. There is a strong tendency for firms to support education and youth work; insofar the basic tenor is that (owner)-managers select projects in which they have a personal interest (see also Dincer and Dincer, 2013). With regard to general decision criteria, the data mainly indicate three aspects that inform the decision on social projects and community-linked activities:

- Local relationship: This involves a regional linkage and/or a personal interest or connection of the participant or employees of the firm in supported projects;

- Resource orientation: This mainly refers to a budget-oriented way of deciding which projects are being supported, such as first come, first served;

- Win-win approach: This approach expects that the firms will get something in return for their engagement - for example, when a sports club is supported, that it will contribute to a company celebration.

The analysis of data clearly indicates a local focus of the engagement, which is also widely echoed in literature (Heblich and Gold, 2010; Jenkins, 2006; Spence and Perrini, 2009; Spence et al., 2003). There were only a few references to international projects, and these were mostly prompted by a personal interest of the owner(s). This mentality can be illustrated by the following quote:

'There certainly are many bad things taking place around the world and in Africa and elsewhere. But I believe that we do not have to look at Africa in the future. We can already see misery here in the region and personally I prefer to give support here.' (Owner-Manager - Company R) 
It is important to note that the decision criteria listed above are not independent from each other. There is often a dynamic between locality and the availability of resources. Surprisingly, participants did not report any figures on the budget available for such projects, but these may vary greatly among firms, and may ultimately rely on firm size and the actual economic situation. As SMEs strive for flexibility in their responsibility engagement, an ad hoc approach is preferred (Sen and Cowley, 2013). However, it is likely that budgets are relatively small. Participants also reported allocating budgets across a range of projects in order to spread benefits across a arrange of stakeholders. One firm noted that 80 per cent of the budget goes to long-term arranged projects and 20 per cent can be handled more flexibly (MD of company H). The last point (win-win motivation) ultimately guides the engagement of many firms. For instance, supporting education can be seen in this light. Given the economic rationale by which the participants seem to be characterised, it is likely to assume that most of the participants do not engage solely out of a moral consciousness. This point should be carefully considered as it may indicate that the SMEs may not have as many resources to spend on such purposes but they seem to live the (limited) engagement they are involved in rather than pretending to be overly engaged in sustainability.

In summary, the engagement of the participating firms is underpinned by an economic rationale linked to people well-being, although in a very long-term view and under consideration of certain values such as fairness, trust and authenticity. This is reflected in a number of firms refusing to work for, by way of illustration, the arms industry, with firms from states, such as Russia, where corruption may be a problem, and preferring 'inter-SME' business relationships. One of the most interesting findings here is that the special ethos or culture which participants seem to apply tends to be strongly informed by moral values and moral identity. Although we may not argue that SMEs act 
in a sustainability-oriented way, this view may lead to the assumption that many of the participating firms intend to contribute positively to society. Regarding the management approach, there seems to be a predominance of informal approaches; however, a number of firms are mindful of finding a balance between formality and informality, which is often associated with flexibility. Participants engage in sustainability issues for economic reasons - direct ones (cost savings) and indirect ones (higher motivation of employees). However, this does not mean that ideological and ethical reasons do not play a role; rather, the contrary seems evident especially in relation to culturally informed dimensions of employee and local community relations. Aspects of Swabian moral identity acted as a powerful influence and moderator in conjunction with micro-cultural contexts.

\section{Overall discussion and contribution}

Awareness and motivation of owner-managers in the Swabian cultural context of the sample to engage in sustainability activities operated to support harmony, employees and firm longevity. Overall, the data point at a predominant underlying economic rationale and a strong focus on economic and funding/cash flow issues (see also Walther and Schenkel, 2010; Calic and Mosakowski, 2016), which also explains an engagement with tangible sustainability. However, it must be noted that awareness of participants of sustainability varied considerably and was part of a broader narrative ultimately to sustain 'intangible' forms of sustainability which was focused on high identification and bonds with local community and especially the immediate employee sphere in relation to entrepreneurial activity (Pret and Carter, 2017). This was powerfully driven by the Swabian historical-cultural context and antecedents or, following, De Clercq and Voronov, 2011, a Bourdieu-style entrepreneurial habitus (i.e. culturally bound ecosystem). Thus, this research strongly supports literature that sees employees in the centre 
of the awareness of (owner)-managers of SMEs (Hammann et al., 2009; Hoffmann and Maaß, 2009) but here extends this literature by interconnecting moral identity and cultural contextual dimensions (i.e. social capital) (Fuller and Tian, 2006) in the form of microfoundational antecedents for, and social enactment of, actions on sustainability (McKeever, Anderson and Jack 2014).

To elaborate and contextualise the cultural context, while many participating firms were involved in environmental activities (i.e. tangible sustainability), environmental aspects did not seem to have a prima facie high priority. This could be because legal standards regarding the natural environment tend to be strict in Germany (Klein and Vorbohle, 2010). Tangible environmental aspects were seen by participants largely as a business issue, since engagement in this area mostly involves practices that also lead to higher efficiency, lower costs and so on rather than as a 'good' per se. This echoes similar reports identifying environmental considerations as being driven mainly by economic considerations (Bluhm and Geicke, 2008; Castrellon Gutierrez et al., 2014; Meyer et al., 2009; Mittelstädt et al., 2013). This attitude appears to have been intensified by the regional context of Baden-Württemberg. Surprisingly, this long-term perspective was not evidenced as a strongly prevalent or dominating theme in the extant literature. Thus, the data demonstrated that while, what can be termed, tangible sustainability initiatives and practices were engaged with (often through legal compunction), a more potent intangible form of 'sustainability' associated with employee care and well-being (akin to Shepherd and Patzelt, 2011) intrinsically linked to firm survival and longevity were identified as central drivers. A key antecedent of these actions was the sense of employee and owner-manager/managing director responsibility and a moral identity imperative linked to enacting sustainability for regional community identity particularities of Baden-Württemberg. 
How SMEs may perceive their responsibility to society in given contexts is a further major emergent issue. In spite of a strong moral antecedent, most of the participants were unsure about their specific role in society and what is expressly expected from them i.e. they do not see any explicit responsibility besides what they do as a habitual action. There also does not seem to be strong overt pressure to engage in sustainability and responsibility type initiatives beyond legal compulsion. Many participants argue that creating and securing jobs as well as educating young people and, therewith, contributing to the local community or region is their responsibility. Moreover, the business approach of SMEs in the sample seems to be underpinned by values such as fairness, respect or a 'down-to-earth' attitude, especially in 'inter-SME' business relationships. Importantly, participating SMEs did not seek to make explicit and public communication surrounding sustainability instruments; rather, many participating SMEs operated according to some kind of special value-oriented ethos that is implicitly integrated in what SMEs do (Rupp et al., 2013). Thus, there is a strong tendency towards an implicit and intangible sustainability approach and only firms very strongly engaged in tangible sustainability seem to be more explicit and apply, for instance, for some kind of sustainability award. This resonates with contemporaneous research which argues that SMEs tend not to explicitly communicate CSR and sustainability activities, albeit SMEs carry out work closely related to sustainability (Wickert et al., 2016). Our study offers revealing empirical evidence to illuminate this dynamic of tangible and intangible sustainability in association with moral identity antecedents which predicate why this is the case at and the processes by which SME owner-directors and their companies engage with sustainability.

The participants strongly distinguish between managers of large corporations and Owner-Managers of SMEs, and contrast themselves by saying that the former are mostly 
interested in their personal benefit rather than the benefit of the organisation or society. Given this, many participants said that they preferred working with other Mittelstand partners, as the mentality and business behaviour tends to be similar and the SME 'communities' are mutually understood. Surprisingly, the views of the participants indicate a difference between external managers in large corporations and SMEs. There is a tendency that the external managing directors of SMEs argue in a similar way as owner-managers do and apply a similar logic (- a long-term employee-focused perspective), especially after having worked at the same firm for a long period. This results out of the influence of advisory boards, through which owners can articulate their personal strategic objectives; however, it also implies that the culture and the people in SMEs differ from large corporations.

Finally, in relation to drivers of, and barriers to, sustainability engagement, the aim of the argument was not to develop an exhaustive list of drivers and barriers (for this see Kusyk and Lozano, 2007) or discuss them in depth (Laudal, 2011) but rather identify the most influential socially and culturally contextual issues from a local and microfoundational perspective (Xing and Starik, 2017). Here, it was found that ownermanagers/managing directors are central to this question. The importance of the moral identity beliefs and awareness of the (owner)-managers is understood in general terms in SME's (Hatak et al., 2015; Kusyk and Lozano, 2007; Williams and Schaefer, 2013). However, with regard to this, two important points were identified. First, the moral and ethical awareness of the owner managers/managing directors is important as it is linked to their decision whether to invest money in 'tangible' and 'intangible' sustainability. This personal mind-set and consciousness is a decisive factor but this is socially constructed and influenced by geo-spatial regional context. This also indicates that the financial constraints of SMEs, which are so widely reflected in literature, might be 
overemphasised as a barrier to more intense engagement, at least in this fieldwork in the context of Baden-Württemberg. Hence, behavioural micro-foundational factors, such as ethical awareness, may carry more weight in determining and influencing implementing intangible sustainability activities.

Given the regional cultural dimensions highlighted, comparable studies have been undertaken in Berlin (Bader et al., 2007), Saxony-Anhalt (Castrellon Gutierrez et al., 2014; Mittelstädt et al., 2013), Bavaria (Heblich and Gold, 2010) and Hamburg (Klein and Vorbohle, 2010). However, few of these studies consider the contextual influence on sustainability and responsibility engagement and do not surface the subtlety and nuance of the intangible and tangible sustainability divide. With regard to environmental issues, Meyer et al. (2009) could not find any strong regional idiosyncrasies however, the present study has surfaced micro-foundational moral identity antecedents in the BadenWürttemberg context.

The paper makes valuable contributions in a number of ways. There is limited research on sustainability in SMEs (Aragón-Correa et al., 2008; Brammer and Walker, 2012; Morsing and Perrini, 2009; Spence and Painter-Morland, 2010), and especially in a German context (Grothe and Marke, 2012; Walther et al., 2010). This research contributes at least in two ways to this gap. First, it offers a valuable analysis of the SME/Mittelstand literature with regard to sustainability, and moreover complements wider material with a discussion of German research literature identifying the main themes related to this research. Importantly, the paper undertakes a conceptual development of sustainability to recognize the presence and operation of tangible and intangible sustainability forms. More precisely, while much commentary has been dedicated to environmental and green facets of sustainability (characterized in the present argument as 'tangible' sustainability), the impact of issues of values, beliefs and the role 
of culture linked to moral identity have been less explored and these have been pointed at in the present paper by the term 'intangible' sustainability. Second, it conducts primary qualitative fieldwork on a sample of German SMEs and, thus, complements the existing quantitative literature from a regional and contextual background. This has surfaced various dimensions of moral identity in operation in the Swabian SME context in relation to sustainability.

Empirical contributions include a number of conceptualisations developed throughout this research. The data allowed conceptualization of the long-term orientation of SMEs linked to tangible sustainability. An important point here is that the application of a longer time-frame allows investments and developments, which could not be reached within shorter time frames, and the pressure of capital markets to achieve a certain profitability within one or two years. This could be seen as a major point that gives SMEs in the sample the chance to position themselves successfully in niche markets and develop unique competencies. Such a long-term orientation can be associated with a more sustainable way of doing business, especially when combining long-term orientation with the value-oriented mentality or moral identity.

A moral identity lens thus assists in analysing the relationship with employees and the local community. The literature develops relevance for a moral identity-informed view to complement prevailing stakeholder perspectives for SMEs. Here, it is argued that the combination of both views provides a more thorough approach to analyse the engagement of SMEs. The locally embedded nature of SMEs provides a cultural systematisation of the structural moral identities which inform relationships. SMEs have a multifaceted network especially in a local context or with other SME business partners, such as suppliers or customers; however, these local networks do not seem overly extensive and SMEs in the sample seem to primarily focus on their close business 
relationships. Especially in business relationships, the participants indicate that personal contact and trust is essential. This is especially true when looking at the cooperation between SMEs.

\section{Limitations}

As with all research activity, this study also has several limitations. Adopting an interpretive approach involves in-depth smaller sample sizes (Saunders, 2012). In this research, the findings are based on a collection of purposively sampled interviews and extended discussions with owner managers and managing directors of SMEs. Hence, findings cannot be considered to be representative for the whole population of SMEs. Moreover, the fieldwork focused on manufacturing SMEs in a particular region (BadenWürttemberg) with implications for preliminary generalizability.

Furthermore, the findings in this research are mainly based on data created through personal interviews with one participant per firm. Although this is compared to complementary data such as company websites and extensively with the literature, the interview data forms the most important source of knowledge and no other primary data source has been used (Kvale and Brinkmann, 2009). When doing research in areas that involve moral issues and so on, socially desirable answers represent a threat to the usefulness of the data. It also seems likely that firms which are more strongly engaged in sustainability and responsibility participate in such research while the 'ordinary' firms tend to be reluctant to be involved. However, it must be noted that Baden-Württemberg is one of the most economically successful regions worldwide; hence, firms in this area might be in a better economic and financial position compared to other regions. So, this finding could not necessarily be transferred to other regions to the same extent.

Regarding the methodological area, further research should consider different kinds of participants. While owner-managers and managing directors are a major source 
of knowledge, it would be helpful to gather data from employees across different hierarchies, officials in local authorities and business associations, consultants strongly engaged in sustainability in an SME context and so on. This could considerably widen the perspective of knowledge, as it provides views from different angles on the phenomena under research. Moreover, future research should focus on other regions and/or industries in Germany and beyond, in order to build a mosaic of a heterogeneous research field.

\section{Implications}

The findings and contributions of this research provide a number of implications for SMEs. The conceptual development of the paper evolved and introduced the notion of tangible and intangible sustainability which allows deeper exploration of the range of factors and drivers which underpin each. As indicated, for SME (Mittelstand) firms intangible sustainability linked to moral identity in the firm emerged as centrally significant. The fieldwork indicates that SMEs in the sample principally follow a longterm intangible sustainability perspective and are less short-term profit-oriented (in contrast to many MNCs). Moreover, they implicitly apply a special mentality that is underpinned by certain values. This is a major point that may allow SMEs to reflect on, recognise and consolidate extant practices which affirm a more sustainable way of doing business. However, SMEs in the sample, experience considerable pressure from large corporations, which may reduce this possibility. Hence, owner-managers with the desire to pursue in a mindful manner a more intangible sustainable way of doing business should strive to maintain the longer-term employee and community well-being through a strong connectedness with regional moral identities. Such mindsets and actions will need to be responsive to the localised and micro-cultural and contextual factors which exist in particular spatial (geographic) and temporal (period/epoch) settings. 


\section{References}

Albert, M. and Rauf, G. (1996). The Future of Rhenish Capitalism. Political Quarterly, 67(3), 184-193.

Alvesson, M. and Ashcraft, K. L. (2012). Interviews. In G. Symon and C. Cassell (Eds.), Qualitative Organizational Research: Core Methods and Current Challenges (pp. 239-257). London et al.: Sage.

Anderson, A.R. and Smith, R. (2007). The moral space in entrepreneurship: an exploration of ethical imperatives and the moral legitimacy of being enterprising. Entrepreneurship and Regional Development, 19(6), pp.479-497.

Aquino, K., Freeman, D., Reed, A., Felps, W. and Lim, V. K., (2009). Testing a socialcognitive model of moral behaviour: the interactive influence of situations and moral identity centrality. Journal of Personality and Social Psychology, 97(1), $123-141$.

Aragón-Correa, J. A., Hurtado-Torres, N., Sharma, S. and García-Morals, V. J. (2008). Environmental strategy and performance in small firms: a resource-based perspective. Journal of Environmental Management, 86(1), 88-103.

Asif, M., Searcy, C., Zutshi, A. and Ahmad, N. (2011). An integrated management systems approach to corporate sustainability. European Business Review, 23(4), $353-367$.

Audretsch, D. B. and Elston, J. A. (2002). Does firm size matter? Evidence on the impact of liquidity constraints on firm investment behaviour in Germany. International Journal of Industrial Organization, 20(1), 1-17.

Avram, D. O. and Kühne, S. (2008). Implementing responsible business behaviour from a strategic management perspective: Developing a framework for Austrian SMEs. Journal of Business Ethics, 82(2), 463-475.

Bader, N., Bauerfeind, R. and Giese, C. (2007). Corporate Social Responsibility (CSR) bei kleinen und mittelständischen Unternehmen in Berlin. Berlin. Retrieved from http://www.ihkberlin.de/linkableblob/bihk24/standortpolitik/downloads/ 818292/.9./data/Studie_CSR_in_Berlin-data.pdf.

Bakker, F. G. A. de, Groenewegen, P. and Hond, F. den. (2005). A Bibliometric Analysis of 30 Years of Research and Theory on Corporate Social 
Responsibility and Corporate Social Performance. Business and Society, 44(3), $283-317$.

Basu, K. and Palazzo, G. (2008). Corporate Social Responsibility: A Process Model of Sensemaking. Academy of Management Review, 33(1), 122-136.

Baumann-Pauly, D., Wickert, C., Spence, L. J. and Scherer, A. G. (2013). Organizing Corporate Social Responsibility in Small and Large Firms: Size Matters. Journal of Business Ethics, 115(4), 693-705.

Bechtle, G. and Lang, C. (1999). Risikosteuerung bei Innovationsprozessen im internationalen Regionalvergleich: Baden-Württemberg und Emilia-Romagna. Retrieved from http://www.isf-muenchen.de/pdf/isf-archiv/1999-bechtle-langrisikosteuerung.pdf

Berger, P. L. and Luckmann, T. (1966). The Social Construction of Reality: A Treatise in the Sociology of Knowledge. New York: Anchor Books.

Blasi, (1980) Bridging moral cognition and moral action: A critical review of the literature, Psychological Bulletin, 88, 1-45.

Bluhm, K. and Geicke, A. (2008). Gesellschaftliches Engagement im Mittelstand: altes Phänomen oder neuer Konformismus? In K.-S. Rehberg (Ed.), Die Natur der Gesellschaft: Verhandlungen des 33. Kongresses der Deutschen Gesellschaft für Soziologie in Kassel 2006 (pp. 5699-5713). Frankfurt am Main: Campus Verlag.

BMFSFJ (2010). Frauen in Führungspositionen. Wirtschaft Und Statistik. Retrieved from http://www.bmfsfj.de/RedaktionBMFSFJ/Broschuerenstelle/PdfAnlagen/frauen-in-f_C3_BChrungspositionen-deutsch,property=pdf,bereich $=$ bmfsfj,sprache $=$ de, $r w b=$ true.pdf

BMU/UBA (2015). Umweltbewusstsein in Deutschland 2014: Ergebnisse einer repräsentativen Bevölkerungsumfrage. Retrieved from bundesamt.de/sites/default/files/medien/378/publikationen/umweltbewusstsein_i n_deutschland.pdf

Boiral, O., Baron, C. and Gunnlaugson, O. (2014). Environmental Leadership and Consciousness Development: A Case Study Among Canadian SMEs. Journal of Business Ethics, 123(3), 363-383.

Boje, D., Gephart, R. and Thatchenkery, T. (1996) Postmodern Management and Organization Theory, London, Sage Publications. 
Bradford, J. and Fraser, E. D. G. (2008). Local Authorities, Climate Change and Small and Medium Enterprises: Identifying Effective and Carbon Emissions. Corporate Social Responsibility and Environmental Management, 15(3), 156172.

Brammer, S. and Walker, H. (2012) The relationship between sustainable procurement and e-procurement in the public sector. International Journal of Production Economics, 140 (1), 256-268.

Braun, V. and Clarke, V. (2006). Using thematic analysis in psychology. Qualitative Research in Psychology, 3(2), 37-41.

Burns, P. (2011). Entrepreneurship \& Small Business: Start up, Growth and Maturity. Basingstoke: Palgrave Macmillan.

Burton, B. K. and Goldsby, M. (2009). Corporate Social Responsibility Orientation, Goals, and Behaviour: A Study of Small Business Owners. Business and Society, 48(1), 88-104.

Calic, G., \& Mosakowski, E. (2016). Kicking off social entrepreneurship: How a sustainability orientation influences crowdfunding success. Journal of Management Studies, 53(5), 738-767.

Carr, P. (2003). Revisiting the Protestant Ethic and the Spirit of Capitalism:

Understanding the Relationship between Ethics and Enterprise. Journal of Business, 47(1), 7-16.

Carroll, A. B. (1979). A Three-Dimensional Conceptual Model of Corporate Performance. The Academy of Management Review, 4(4), 497-505.

Castrellon Gutierrez, B., Mittelstädt, F. and Zabel, H.-U. (2014). Nachhaltigkeits- und Energiemanagement - theoretischer Ansatz und empirische Befunde für kleine und mittlere Unternehmen (KMU) in Sachsen-Anhalt. In J.-A. Meyer (Ed.), Energie- und Umweltmanagement in kleinen und mittleren Unternehmen (pp. 149-184). Lohmar/Cologne: Eul Verlag.

Chandler, A. D. (1990). Scale and Scope: The Dynamics of Industrial Capitalism. Cambridge: Harvard University Press.

Chang, Y. K., Weaver, G. R. and Kim, T. G. (2015). Moral Identity and Moral Emotion Experience: A Cross-cultural Analysis. Paper presented at the Academy of Management Proceedings.

Chaston, I. (2010). Entrepreneurial Management in Small Firms. London: Sage. 
Clegg, S. R. (2012). The end of bureaucracy. Research in the Sociology of Organizations, 35, 59-84.

Coffey, A. and Atkinson, P. (1996). Making Sense of Qualitative Data: Complementary Research Strategies. Thousand Oaks: Sage.

Cost, H. (2006). Die Wirtschaft Baden-Württembergs. In R. Weber and H.-G. Wehling (Eds.), Baden-Württemberg: Gesellschaft, Geschichte, Politik (pp. 217-237). Stuttgart: Kohlhammer.

Crane, A. and Matten, D. (2010). Business Ethics: Managing Corporate Citizenship and Sustainability in the Age of Globalization (3rd. ed.). Oxford: Oxford University Press.

Crilly, D., Hansen, M. and Zollo, M. (2016). The Grammar of Decoupling: A Cognitive-Linguistic Perspective on Firms' Sustainability Claims and Stakeholders' Interpretation. Academy of Management Journal, 59(2), 705-729.

Curran, J. and Blackburn, R. A. (2001). Researching the Small Enterprise. London: Sage.

Davidsson, P. (2004). Researching Entrepreneurship. New York: Springer.

De Clercq, D., \& Voronov, M. (2011). Sustainability in entrepreneurship: A tale of two logics. International Small Business Journal, 29(4), 322-344.

De Groot, J. I. M. and Steg, L. (2009). Morality and prosocial behaviour: The role of awareness, responsibility, and norms in the norm activation model. The Journal of Social Psychology, 149(4), 425-449.

Deutsche Bundesbank. (2012). Die langfristige Entwicklung der Unternehmensfinanzierung in Deutschland - Ergebnisse der gesamtwirtschaftlichen Finanzierungsrechnung. Deutsche Bundesbank Monatsbericht, January, 13-28.

Dey, I. (1993). Qualitative Data Analysis: A User-Friendly Guide for Social Scientists. London: Routledge.

Dincer, B. and Dincer, C. (2013). Corporate social responsibility decisions: a dilemma for SME executives? Social Responsibility Journal, 9(2), 177-187.

Dustmann, C., Fitzenberger, B., Schönberg, U., and Spitz-Oener, A. (2014). From Sick Man of Europe to Economic Superstar: Germany’s Resurgent Economy. Journal of Economic Perspectives, 28(1), 167-188.

Dutton, J. E, Roberts, L. M. and Bednar, J. (2010). Pathways for positive identity construction at work: Four types of positive identity and the building of social resources. Academy of Management Review, 35(2), 265-293. 
Dyllick, T. and Hockerts, K. (2002). Beyond the business case for corporate sustainability. Business Strategy and the Environment, 11(2), 130-141.

Elkington, J. (1997). Cannibals with Forks: The Tripple Bottom Line of 21st Century Business. Oxford: Capstone.

Enderle, G. (2004). Global competition and corporate responsibilities of small and medium-sized enterprises. Business Ethics: A European Review, 13(1), 51-63.

Fraj-Andrés, E., López-Pérez, M. E., Melero-Polo, I. and Vázquez-Carrasco, R. (2012). Company image and corporate social responsibility: reflecting with SMEs' managers. Marketing Intelligence and Planning, 30(2), 266-280.

Friedman, M. (1970). The Social Responsibility of Business is to Increase Its Profits. New York Times Magazin. Retrieved from http://www.colorado.edu/student groups/libertarians/issues/friedman-soc-resp-business.html

Fuller, T. and Tian, Y. (2006). Social and Symbolic Capital and Responsible Entrepreneurship: An Empirical Investigation of SME Narratives. Journal of Business Ethics, 67(3), 287-304.

Gergen, K. J. (2009). An Invitation to Social Construction (2nd ed.). London et al.: Sage.

Gibbs, G. R. (2007). Analyzing Qualitative Data. London: Sage.

Gioia, D. A., Corley, K. G., \& Hamilton, A. L. (2013). Seeking qualitative rigor in inductive research: Notes on the Gioia methodology. Organizational Research Methods, 16(1), 15-31.

Giacalone, R. and Rosenfeld, P. (1989) Impression Management in the Organization, New Jersey, Lawrence Erlbaum Associates.

Giacalone, R., Rosenfeld, P. and Riordan, C. (2001) Impression Management: Building and Enhancing Reputations at Work, New York, Cengage Learning.

Grothe, A. and Marke, N. (2012). Nachhaltiges Wirtschaften - eine besondere Herausforderung für KMU. In A. Grothe (Ed.), Nachhaltiges Wirtschaften für KMU: Ansätze zur Implementierung von Nachhaltigkeitsaspekten (pp. 26-35). Munich: oekom.

Habisch, A. (2004). Social Responsibility, Social Capital and SMEs. In L. J. Spence, A. Habisch, and R. Schmidpeter (Eds.), Responsibility and Social Capital: The World of Small and Medium Sized Enterprises (pp. 25-34). Basingstoke: Palgrave Macmillan. 
Habisch, A., Patelli, L., Pedrini, M. and Schwartz, C. (2011). Different Talks with Different Folks: A Comparative Survey of Stakeholder Dialog in Germany, Italy, and the U.S. Journal of Business Ethics, 100(3), 381-404.

Habisch, A. and Wegner, M. (2005). Overcoming the Heritage of Corporatism. In A. Habisch, J. Jonker, M. Wegner, and R. Schmidpeter (Eds.), Corporate Social Responsibility Across Europe (pp. 111-123). Berlin: Springer.

Haidt, J. (2003). The moral emotions. In R. J. Davidson, K. R. Scherer and H. H. Goldsmith (Eds.), Handbook of affective sciences (pp. 852-870). New York, NY, US: Oxford University Press.

Hankinson, A., Bartlett, D., and Ducheneaut, B. (1997). The key factors in the small profiles of small-medium enterprise owner-managers that influence business performance: The UK (Rennes) SME survey 1995-1997 An international research project UK survey. International Journal of Entrepreneurial Behaviour \& Research, 3(3), 168-175.

Hammann, E.-M., Habisch, A. and Pechlaner, H. (2009). Values that create value: socially responsible business practices in SMEs - empirical evidence from German companies. Business Ethics: A European Review, 18(1), 37-51.

Hardy, S. A. (2006). Identity, reasoning, and emotion: An empirical comparison of three sources of moral motivation. Motivation and Emotion, 30(3), 205-213.

Hassel, A. (2014). The paradox of liberalization - understanding dualism and the recovery of the German political economy. British Journal of Industrial Relations, 52(1), 57-81.

Hatak, I., Floh, A. and Zauner, A. (2015). Working on a dream: sustainable organisational change in SMEs using the example of the Austrian wine industry. Review of Managerial Science, 9(2), 285-315.

Healey, M. J. and Rawlinson, M. B. (1993). Interviewing business owners and managers: a review of methods and techniques. Geoforum, 24(3), 339-355.

Heblich, S. and Gold, R. (2008). Corporate Social Responsibility: Eine Win-Win Strategie für Unternehmen und Regionen. Jena. Retrieved from http://www.upj.de/fileadmin/user_upload/MAIN-dateien/Infopool/ Forschung/maxplanck_csr_regionen08.pdf

Heblich, S. and Gold, R. (2010). Corporate Social Responsibility: Eine Win-Win Strategie für Unternehmen und Regionen. In H. Pechlaner and M. Bachinger 
(Eds.), Lebensqualität und Standortattraktivität: Kultur, Mobilität und regionale Marken als Erfolgsfaktoren (pp. 333-358). Berlin: Erich Schmidt Verlag.

Herrigel, G. (1996). Industrial Constructions: The Sources of German Industrial Power. Cambridge: Cambridge University Press.

Hiss, S. (2009). From Implicit to Explicit Corporate Social Responsibility: Institutional Change as a Fight for Myths. Business Ethics Quarterly, 19(3), 433-452.

Hoffmann, M. and Maaß, F. (2009). Corporate Social Responsibility als Erfolgsfaktor einer stakeholderbezogenen Führungsstrategie? Ergebnisse einer empirischen Untersuchung. In I. für Mittelstandsforschung (Ed.), Jahrbuch zur Mittelstandsforschung 2008 (pp. 1-51). Wiesbaden: Gabler.

Holland, L. and Gibbon, J. (1997). SMEs in the Metal Manufacturing, Construction and Contracting Service Sectors: Environmental Awareness and Actions. EcoManagement and Auditing, 4(1), 7-14.

Holstein, J. A. and Gubrium, J. F. (1995). The Active Interview. Thousand Oaks et al.: Sage University Paper Series.

Hopwood, B., Mellor, M. and O’Brien, G. (2005). Sustainable development: mapping different approaches. Sustainable Development, 13(1), 38-52.

IW (2005). OECD-Länder Im Standortvergleich: Struktur, Vorgehen, Datenbasis, Ranking. Cologne. Retrieved from http://www.iwkoeln.de/de/studien/gutachten/ beitrag/63939

Jenkins, H. (2004). A Critique of Conventional CSR Theory: An SME Perspective. Journal of General Management, 29(4), 37-57.

Jenkins, H. (2006). Small Business Champions for Corporate Social Responsibility. Journal of Business Ethics, 67(3), 241-256.

Kincaid, H. V. and Bright, M. (1957). Interviewing the Business Elite. American Journal of Sociology, 63(3), 304-311.

King, N. (1998). Template Analysis. In G. Symon and C. Cassell (Eds.), Qualitative Methods and Analysis in Organizational Research: A Practical Guide (pp. 118134). London: Sage.

King, N. (2004). Using Interviews in Qualitative Research. In C. Cassell and G. Symon (Eds.), Essential Guide to Qualitative Methods in Organizational Research (pp. 11-22). London: Sage. 
King, N. (2012). Doing Template Analysis. In G. Symon and C. Cassell (Eds.), Qualitative Organizational Research: Core Methods and Current Challenges (pp. 426-450). London: Sage.

King, N. and Horrocks, C. (2010). Interviews in Qualitative Research. London: Sage. Klein, S. and Vorbohle, K. (2010). Corporate Social Responsibility and Stakeholder Relations - The Perspective of German Small and Medium-Sized Enterprises. In L. Spence and M. Painter-Morland (Eds.), Ethics in Small and Medium Sized Enterprises: A Global Commentary (pp. 215-225). Dordrecht et al: Springer. Kohlberg, L. (1971) From is to ought: how to commit the naturalistic fallacy and get away with it in the study of moral development. In Mischel, T. Cognitive Development and Epistemology, New York, Academic Press, pp.164-165. Koiranen, M. (2002). Over 100 Years of Age But Still Entrepreneurially Active in Business: Exploring the Values and Family Characteristics of Old Finnish Family Firms. Family Business Review, 15(3), 175-187.

Korsgaard, S., \& Anderson, A. R. (2011). Enacting entrepreneurship as social value creation. International Small Business Journal, 29(2), 135-151.

Krämer, W. (2003). Mittelstandsökonomik: Grundzüge einer umfassenden Analyse kleiner und mittlerer Unternehmen. Munich: Verlag Franz Vahlen.

Kusyk, S. M. and Lozano, J. M. (2007). Corporate responsibility in small and mediumsized enterprises. SME social performance: a four-cell typology of key drivers and barriers on social issues and their implications for stakeholder theory. Corporate Governance, 7(4), 502-515.

Kvale, S. and Brinkmann, S. (2009). InterViews: Learning the Craft of Qualitative Research Interviewing (2nd ed.). Thousand Oaks et al.: Sage.

Lähdesmäki, M. and Takala, T. (2012). Altruism in business - an empirical study of philanthropy in the small business context. Social Responsibility Journal, 8(3), 373-388.

Landeszentrale für politische Bildung. (2001). Regionen in Baden-Württemberg. Politik und Unterricht: Zeitschrift für die Praxis der politischen Bildung, 27(1).

Laudal, T. (2011). Drivers and barriers of CSR and the size and internationalization of firms. Social Responsibility Journal, 7(2), 234-256.

Lee, K.-H., Herold, D. M. and Yu, A.-L. (2016). Small and Medium Enterprises and Corporate Social Responsibility Practice: A Swedish Perspective. Corporate Social Responsibility and Environmental Management, 23(2), 88-99. 
Lee, M.-D. P. (2008). A review of the theories of corporate social responsibility: Its evolutionary path and the road ahead. International Journal of Management Reviews, 10(1), 53-73.

Lindgreen, A. and Swaen, V. (2010). Corporate Social Responsibility. International Journal of Management Reviews, 12(1), 1-7.

Liu, Y., and Meyer, K. E. (2018). Boundary spanners, HRM practices, and reverse knowledge transfer: The case of Chinese cross-border acquisitions. Journal of World Business. https://doi.org/10.1016/j.jwb.2018.07.007

Liu, Y., Öberg, C., Tarba, S. Y., and Xing, Y. (2018). Brand management in Mergers and Acquisitions: Emerging market multinationals venturing into advanced economies. International Marketing Review, 35(5), 710-732.

Lozano, R. (2008). Envisioning sustainability three-dimensionally. Journal of Cleaner Production, 16(17), 1838-1846.

Lyotard, J-F. (1984). Post-modern Condition: A Report on Knowledge. University of Minnesota Press.

Markman, G. D., Russo, M., Lumpkin, G. T., Jennings, P. D., \& Mair, J. (2016). Entrepreneurship as a platform for pursuing multiple goals: A special issue on sustainability, ethics, and entrepreneurship. Journal of Management Studies, 53(5), 673-694.

Masurel, E. (2007). Why SMEs invest in environmental measures: Sustainability evidence from small and medium-sized printing firms. Business Strategy and the Environment, 16(3), 190-201.

Mathews, M. and Stokes, P. (2013) The Creation of Trust - The Interplay of Rationality, Institutions and Exchange, Entrepreneurship and Regional Development 25(9-10): 845-866.

Mathieu, P. (2002). Unternehmen auf dem Weg zu einer nachhaltigen Wirtschaftsweise: Theoretische Grundlagen - Praxisbeispiele aus Deutschland - Orientierungshilfe. Wiesbaden: Gabler.

Matten, D., and Moon, J. (2008). "Implicit" and "explicit" CSR: A conceptual framework for a comparative understanding of corporate social responsibility. Academy of Management Review, 33(2), 404-424.

Mayer, D., Aquino, K., Greenbaum, R. and Kuenzi, M. (2012) 'Who displays ethical leadership and why does it matter?: An examination of antecedents and 
consequences of ethical leadership, Academy of Management Journal, 55(1), $151-171$.

McKeever, E., Anderson, A. and Jack, S. (2014). Entrepreneurship and mutuality: social capital in processes and practices. Entrepreneurship \& Regional Development, 26(5-6), pp.453-477.

Meyer, J.-A., Tirpitz, A. and Laß, D. (2009). Energie- und Umweltverhalten im Mittelstand. Lohmar/Cologne: Eul Verlag.

Mittelstädt, F., Backhaus-Maul, H. and Kunze, M. (2013). Gesellschaftliches und ökologisches Engagement von Unternehmen ( CSR ) in Sachsen-Anhalt: Ergebnisse einer Unternehmensbefragung von kleinen und mittleren Unternehmen (No. 3). Halle (Saale). Retrieved from http://www.csr-sachsenanhalt.de/Forschungsbericht.pdf

Montiel, I. and Delgado-Ceballos, J. (2014). Defining and Measuring Corporate Sustainability: Are We There Yet? Organization and Environment, 27(2), 1-27.

Moon, J. (2007). The Contribution of Corporate Social Responsibility to Sustainable Development. Sustainable Development, 15(5), 296-306.

Moore, C. and Gino, F. (2015). Approach, ability, aftermath: A psychological process framework of unethical behaviour at work. The Academy of Management Annals, 9(1), 235-289.

Morsing, M. and Perrini, F. (2009). CSR in SMEs: do SMEs matter for the CSR agenda? Business Ethics: A European Review, 18(1), 1-6.

Moyser, G. and Wagstaffe, M. (1987). Studying elites: theoretical and methodological issues. In G. Moyser and M. Wagstaffe (Eds.), Research Methods for Elite Studies (pp. 1-24). London: Allen and Unwin.

Norton, T. A., Parker, S. L., Zacher, H. and Ashkanasy, N. M. (2015). Employee Green Behaviour: A Theoretical Framework, Multilevel Review, and Future Research Agenda. Organization and Environment, 28(1), 103-125.

Okoye, A. (2009). Theorising Corporate Social Responsibility as an Essentially Contested Concept: Is a Definition Necessary? Journal of Business Ethics, 89(4), 613-627.

Palazzo, B. (2002). U.S.-American and German Business Ethics: An Intercultural Comparison. Journal of Business Ethics, 41(3), 195-216. 
Parkin, S., Sommer, F. and Uren, S. (2003). Sustainable development: understanding the concept and practical challenge. Proceedings of the Institution of Civil Engineers, 156(ESI), 19-26.

Penrose, E. (2009). The Growth of the Firm (4th ed.). Oxford: Oxford University Press. Piaget, J. (1932) The Moral Judgement of the Child, New York, Free Press.

Portes, A. (1998). Social Capital: Its Origins and Applications in Modern Sociology. Annual Review of Sociology, 24, 1-24.

Pret, T. and Carter, S. (2017). The importance of 'fitting in': collaboration and social value creation in response to community norms and expectations. Entrepreneurship \& Regional Development, 29(7-8), 639 - 667.

Reindl, J. (2003). Warum Baden-Württemberg der Toscana überlegen ist - ein interregionaler Vergleich von Produktionsmodellen. Leviathan, 31(2), 242-257.

Rest, J. (1979) Development in Judging Moral Issues, Minneapolis, University of Minnesota Press.

Rogall, H. (2009). Nachhaltige Ökonomie: Ökonomische Theorie und Praxis einer Nachhaltigen Entwicklung. Marburg: Metropolis.

Rogers, P. P., Jalal, K. F. and Boyd, J. A. (2008). An Introduction to Sustainable Development. London: Earthscan.

Rupp, D. E., Shao, R., Thornton, M. A. and Skarlicki, D. P. (2013). Applicants' and employees' reactions to corporate social responsibility: The moderating effects of first-party justice perceptions and moral identity. Personnel Psychology, 66(4), 895-933.

Santos, M. (2011). CSR in SMEs: strategies, practices, motivations and obstacles. Social Responsibility Journal, 7(3), 490-508.

Saunders, M. N. K. (2012). Choosing research participants. In G. Symon and C. Cassell (Eds.), Qualitative Organizational Research: Core Methods and Current Challenges (pp. 35-52). London et al.: Sage.

Sen, S. and Cowley, J. (2013). The Relevance of Stakeholder Theory and Social Capital Theory in the Context of CSR in SMEs: An Australian Perspective. Journal of Business Ethics, 118(2), 413-427.

Shao, R., Aquino, K. and Freeman, D. (2008) Beyond moral reasoning: A review of moral identity research and its implications for business ethics. Business Ethics Quarterly, 18(4), 513-540. 
Shepherd, D. A., \& Patzelt, H. (2011). The new field of sustainable entrepreneurship: Studying entrepreneurial action linking "what is to be sustained" with "what is to be developed". Entrepreneurship Theory and Practice, 35(1), 137-163.

Shevchenko, A., Lévesque, M., \& Pagell, M. (2016). Why firms delay reaching true sustainability. Journal of Management Studies, 53(5), 911-935.

Silverman, D. (2011). Interpreting Qualitative Data (4th ed.). London et al.: Sage.

Snape, D. and Spencer, L. (2003). The Foundations of Qualitative Research. In J. Ritchie and J. Lewis (Eds.), Qualitative Research Practice: A Guide for Social Science Students and Researchers (pp. 1-23). London: Sage.

Solomon, R. C. and Martin, C. (2004). Above the Bottom Line: An Introduction to Business Ethics (3rd ed.). Belmont: Wadsworth/Thomson Learning.

Spence, L. J. (1999). Does size matter? The state of the art in small business ethics. Business Ethics: A European Review, 8(3), 163-174.

Spence, L. J. (2007). CSR and Small Business in a European Policy Context: The Five "C"s of CSR and Small Business Research Agenda 2007. Business and Society Review, 112(4), 533-552.

Spence, L. J. (2016). Small Business Social Responsibility: Expanding Core CSR Theory. Business and Society, 55(1) 23-55.

Spence, L. J. and Painter-Morland, M. (2010). Introduction: Ethics in Small and Medium Sized Enterprises. In L. J. Spence and M. Painter-Morland (Eds.), Ethics in Small and Medium Sized Enterprises: A Global Commentary (pp. 19). Dordrecht et al.: Springer.

Spence, L. J. and Perrini, F. (2009). Practice and politics: Ethics and social responsibility in SMEs in the European union. African Journal of Business Ethics, 4(2), 20-31.

Spence, L. J. and Rutherfoord, R. (2003). Small Business and Empirical Perspectives in Business Ethics: Editorial. Journal of Business Ethics, 47(1), 1-5.

Spence, L. J. Schmidpeter, R. and Habisch, A. (2003). Assessing Social Capital: Small and Medium Sized Enterprises in Germany and the U.K. Journal of Business Ethics, 47(1), 17-29.

Storey, D. J., and Greene, F. J. (2010). Small Business and Entrepreneurship. Harlow: Pearson. 
Statistisches Landesamt Baden-Württemberg (2013). Baden-Württemberg - ein Standort im Vergleich. Stuttgart. Retrieved from http://www.statistik.badenwuerttemberg.de/Veroeffentl/803613101.pdf

Stieb, J. A. (2009). Assessing Freeman's Stakeholder Theory. Journal of Business Ethics, 87(3), 401-414.

Stokes, P. (2011) Critical Concepts in Management and Organization Studies Basingstoke, Palgrave-Macmillan.

Stokes, P. (2016) Organizational Management: Approaches and Solutions, London, Kogan Page.

Stokes, P., Liu, Y., Smith, S., Leidner, S., Moore, N. and Rowland, C. (2015). Managing talent across advanced and emerging economies: HR issues and challenges in a Sino-German strategic collaboration. The International Journal of Human Resource Management, 1-29.

Tänzler, J. K. (2014). Corporate Governance und Corporate Social Responsibility im deutschen Mittelstand. Lohmar/Cologne: Eul Verlag.

Thompson, J. K. and Smith, H. L. (1991). Social Responsibility and Small Business: Suggestions for Research. Journal of Small Business Management, 29(1), 3045.

Uhlaner, L. M., Berent-Braun, M. M., Jeurissen, R. J. M. and de Wit, G. (2012). Beyond size: Predicting engagement in environmental management practices of Dutch SMEs. Journal of Business Ethics, 109(4), 411-429.

Uhlaner, L. M., Goor-Balk, H. J. M. (Annemieke) van, and Masurel, E. (2004). Family business and corporate social responsibility in a sample of Dutch firms. Journal of Small Business and Enterprise Development, 11(2), 186-194.

Urry, J. and Larsen, J. (2011). The Tourist Gaze, 3.0, London, Sage Publications Useem, M. (1995). Reaching Corporate Executives. In R. Hertz and J. B. Imber (Eds.), Studying Elites Using Qualitative Methods (pp. 18-39). Thousand Oaks: Sage.

Villegas de Posada, C. and Vargas-Trujillo, E. (2015). Moral reasoning and personal behaviour: A meta-analytical review. Review of General Psychology, 19(4), 408 -424 .

Walther, M. and Schenkel, M. (2010). Herausforderung CSR: Strategie und Selbstwahrnehmung mittelständischer Unternehmen. In J.-A. Meyer (Ed.), Strategien von kleinen und mittleren Unternehmen (pp. 77-96).

Lohmar/Cologne: Eul Verlag. 
Weber, R. and Wehling, H.-G. (2012). Geschichte Baden-Württembergs (2nd ed.). München: C.H. Beck.

Wehling, H.-G. (2004). Baden-Württemberg: Nach Gestalt und Traditionen von großer Vielfalt. In H.-G. Wehling (Ed.), Die deutschen Länder: Geschichte, Politik, Wirtschaft (3rd ed., pp. 17-34). Wiesbaden: Verlag für Sozialwissenschaften.

Weick, K. (1995) Sensemaking in Organizations, Thousand Oaks, Sage Publications.

Welsh, J. A., and White, J. F. (1981). A Small Business is not a Little Big Business. Harvard Business Review, 59(4), 18-32.

Werner, A. and Spence, L. J. (2004). Literature Review: Social Capital and SMEs. In L. J. Spence, A. Habisch, and R. Schmidpeter (Eds.), Responsibility and Social Capital: The World of Small and Medium Sized Enterprises (pp. 7-24). Basingstoke: Palgrave Macmillan.

Wickert, C., Scherer, A. G. and Spence, L. J. (2016). Walking and talking corporate social responsibility: Implications of firm size and organizational cost. Journal of Management Studies, 53(7), 1169-1196.

Williams, S. and Schaefer, A. (2013). Small and Medium-Sized Enterprises and Sustainability: Managers' Values and Engagement with Environmental and Climate Change Issues. Business Strategy and the Environment, 22(3), 173-186.

Winkler, I. and Remišová, A. (2007). Do corporate codes of ethics reflect issues of societal transformation? Western German and Slovak companies compared. Business Ethics: A European Review, 16(4), 419-431.

Xing, Y., Liu, Y., and Cooper, C. L. (2018). Local government as institutional entrepreneur: Collaborative partnerships in fostering regional entrepreneurship. British Journal of Management. doi:10.1111/1467-8551.12282

Xing, Y., Liu, Y., Tarba, S. and Cooper, C.L. (2017), "Servitization in mergers and acquisitions: manufacturing firms venturing from emerging markets into advanced economies", International Journal of Production Economics, 192(10), 9-18.

Xing, Y., \& Starik, M. (2017). Taoist leadership and employee green behaviour: A cultural and philosophical microfoundation of sustainability. Journal of Organizational Behavior, 38(9), 1302-1319. 